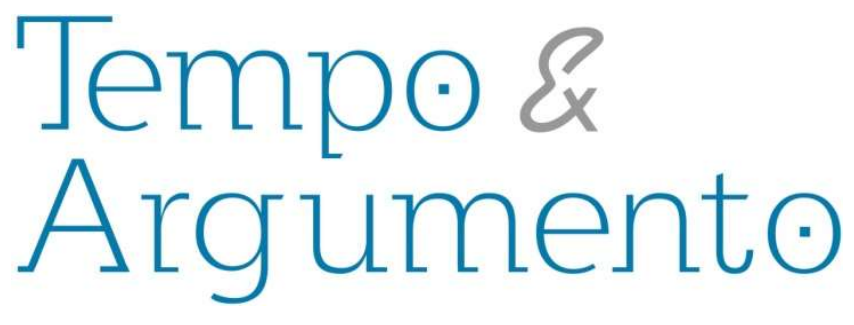

\title{
O humor contra Vargas: desenhos comunistas do período da campanha eleitoral ao suicídio (1950-1954) ${ }^{1}$
}

\begin{abstract}
Resumo
O objetivo deste artigo é analisar as charges e caricaturas sobre Getúlio Vargas publicadas pela imprensa comunista no período compreendido entre a campanha eleitoral de Vargas e seu suicídio (1950-1954), incluindo a reação dos comunistas a esse ato dramático. As imagens da imprensa partidária são usualmente relegadas a segundo plano pela historiografia, mas também expressam a ideologia do Partido Comunista Brasileiro (PCB) e sua leitura da realidade política nacional. Nesse sentido, os personagens presentes nos desenhos e sua caracterização são fontes importantes para a compreensão da leitura comunista de Getúlio Vargas e o contexto daquela época.
\end{abstract}

Palavras-chave: Vargas, Getúlio, 1883-1954; Partido Comunista Brasileiro; Caricatura; Imprensa - Brasil.

\section{Rodrigo Rodriguez Tavares}

Doutor em História Social pela Universidade de São Paulo. Professor adjunto da Universidade Federal do Paraná.

Brasil

rrtvrs@gmail.com

\section{Para citar este artigo:}

TAVARES, Rodrigo Rodriguez. O humor contra Vargas: desenhos comunistas do período da campanha eleitoral ao suicídio (1950-1954). Revista Tempo e Argumento, Florianópolis, v. 8, n. 18, p. 68 - 101. maio/ago. 2016.

\section{DOI: $10.5965 / 2175180308182016068$}

http://dx.doi.org/10.5965/2175180308182016068

\footnotetext{
${ }^{1}$ A pesquisa contou com apoio do Conselho Nacional de Desenvolvimento Científico e Tecnológico (CNPq) e da Coordenação de Aperfeiçoamento de Pessoal de Nível Superior (Capes).
} 


\title{
Humor against Vargas: communist drawings from the election campaign period to suicide (1950-1954)
}

\begin{abstract}
This article aims to analyze the editorial cartoons and caricatures on Getúlio Vargas published by the communist press within the period from Vargas' election campaign to his suicide (1950-1954), including the reaction of communists to this dramatic act. These images by the party press are usually relegated to the background by historiography, but they also express the ideology of the Brazilian Communist Party (PCB) and its reading of the national political reality. Thus, the characters observed in the drawings and their characterization are significant sources for understanding the communist reading of Getúlio Vargas and the context of that time.
\end{abstract}

Keywords: Vargas, Getúlio, 1883-1954; Brazilian

Communist Party; Caricature; Press - Brazil.

\section{Introdução}

A história da caricatura no Brasil deve muito à monumental obra homônima, de Herman Lima (1963). Sua grandeza talvez tenha inibido os pesquisadores da geração seguinte a completar ou atualizar um trabalho de tamanha envergadura, como aventou Pedro Correa do Lago (1999). A obra do pesquisador, desenhista e colecionador Laílson de Holanda Cavalcanti (2005) sobre a história do humor gráfico no Brasil, ao abordar 500 anos de história do país, é a que mais se aproxima do propósito de Lima (1963) pela abrangência e profundidade. Publicada na Espanha, como parte de uma coleção sobre o humor gráfico em diversos países, por vezes, apresenta didatismo sobre a história do Brasil que está diretamente ligado à tentativa de alcançar um público mais amplo, não 
familiarizado com o desenrolar dos acontecimentos no país. Nesse sentido, embora o foco da pesquisa de Cavalcanti (2005) seja a imagem, não são poucos os momentos no livro em que ela meramente ilustra o texto (TAVARES, 2008).

Em relação à historiografia sobre o marxismo, tradicionalmente, o rico repertório de imagens (caricaturas, pôsteres, fotografias etc.) produzidas pelo movimento comunista é praticamente ignorado. No plano internacional, onde diversos partidos comunistas tomaram o poder, o descompasso entre a produção de imagens e a reflexão sobre elas é acentuado. Um dos motivos dessa ausência, sem dúvida, tem relação com a apreciação estética negativa dessas imagens. Ao sufocar as vanguardas e estabelecer-se como arte oficial soviética, o realismo socialista era mal avaliado pelos críticos, considerado uma regressão no surto de criatividade que aflorava na Rússia na era prérevolucionária, cujas obras foram relegadas aos porões. Ao se inspirar no modelo soviético, a arte chinesa, norte-coreana e congêneres acabaram recebendo apreciação similar, embora o mesmo não possa ser dito dos pôsteres cubanos (CUSHING, 2003), que fugiam da rigidez dos ditames soviéticos.

Recentemente, um conjunto de trabalhos internacionais tem tomado esse acervo iconográfico como fonte de pesquisa, reproduzindo pôsteres governamentais e analisando essa propaganda oficial. Tal bibliografia já conta com um volume importante de obras, como as de Stephen White (1988), Stefan Landsberger (1995), Harriet Evans e Stephanie Donald (1999), sendo a obra mais significativa, em abrangência e análise, a de Victoria Bonnel (1997).

Já no Brasil, embora o Partido Comunista Brasileiro (PCB) nunca tenha tomado o poder, a influência estética repressiva do realismo socialista também deixou marcas na arte, como bem demonstrou Dênis de Moraes (1994) e, de certa forma, Jorge Ferreira (2003). No entanto, estudos mais recentes tomam as imagens comunistas como tema de pesquisa. Como ressalta Rodrigo Patto Sá Motta (2013), o campo não é mais totalmente virgem, mas ainda são muitas as possibilidades a ser exploradas dentro da cultura visual comunista. Ainda não há uma visão abrangente acerca do papel da imagem no movimento comunista brasileiro que identifique artistas e técnicas de produção das imagens, investigue a circulação das imagens na imprensa comunista, analise a frequência com que aparecem em determinados períodos, relacione as influências artísticas etc. 
Dentre as pesquisas mais recentes, Rodrigo Patto Sá Motta (2002) tangencia a iconografia comunista ao analisar seu oposto, as imagens e o discurso anticomunista no Brasil, e acaba por analisá-la posteriormente (MOTTA, 2006), além de analisar os embates sobre a figura de Luiz Carlos Prestes em desenhos de diferentes atores sociais (MOTTA, 2004). Já Alberto Gawryszewsky (2004 e 2010), centra sua investigação nessa iconografia e traz um elemento importante ao mostrar a utilização das imagens nas discussões que se seguiram à crise do stalinismo, com a divulgação do relatório Kruschev, em 1956. Paula Elise Ferreira Soares (2011) analisa em profundidade a figura do camponês brasileiro na imprensa e na pintura, partindo de uma imersão nos textos teóricos sobre a questão agrária para compreender as imagens criadas pelos artistas.

Em relação à imprensa comunista, o trabalho de maior alcance cronológico e geográfico continua sendo o de Antônio Rubim (1986). Pela repressão ao partido, obter os exemplares de seus jornais já demanda uma pesquisa árdua, sendo ainda mais difícil localizar os arquivos da redação, entrevistar os jornalistas, reconstruir a dinâmica do cotidiano do jornal, os conflitos etc. No campo visual propriamente dito, a identificação dos desenhistas e dos fotojornalistas também não é simples. A pesquisa sobre o jornal Hoje, de Pedro Pomar (2006), obteve acesso a parte do arquivo do jornal apreendido pela polícia política, o Departamento de Ordem Política e Social (DOPS-SP), o que possibilitou adentrar os meandros da redação, em uma pesquisa que dá atenção às fotografias publicadas no jornal, o que não é usual. Cassandra Gonçalves (2005) investiga uma das experiências mais importantes na produção de imagens comunistas, os Clubes de Gravura, xilogravuras feitas em um esforço de popularizar a arte e baratear sua produção. A experiência dos clubes também é analisada no abrangente estudo de Aracy Amaral (1984) sobre a preocupação social na arte brasileira. Elio Chaves Flores (1999 e 2001) aborda em dois artigos as representações do getulismo, utilizando diversas caricaturas, embora nenhuma dos jornais comunistas. Andrea de Araújo Nogueira (2005) analisa o personagem Zé Marmiteiro, criado por Nelo Lorenzon, um desenhista de esquerda, simpático ao PCB e que dribla o discurso predominante dos jornais Folha da Noite, Folha da Tarde e Folha da Manhã, onde o personagem foi publicado. 


\section{Caricaturas, charges e desenhos}

O objeto desta pesquisa são as representações de Getúlio Vargas nos desenhos da imprensa comunista, para abordar a visão do partido sobre ele. A ênfase nos elementos do desenho não implica ignorar o elemento textual, especialmente aqueles ligados à imagem, como possíveis títulos e legendas, ainda que por vezes estes tenham caráter puramente repetitivo.

Pierre Francastel (1982, p. 1) talvez tenha levado mais longe a ênfase na importância da imagem ao ressaltar que a história

[...] não atribui valor decisivo a não ser ao documento escrito, conferindo-lhe, curiosamente, um valor absoluto, ao passo que recusa o documento figurado ou o monumento. Ela só o emprega para "ilustrar" uma verdade estabelecida em função tão somente das fontes escritas que o acaso pôs em suas mãos.

E, continua o autor:

[...] seria infantil pensar que os únicos valores criados pela história sejam os que a escrita consignou [...] As artes servem, pelo menos tanto quanto as literaturas, como instrumento aos senhores das sociedades para divulgar e impor crenças (FRANCASTEL, 1982, p. 3).

No entanto, como bem ponderou Marcos Silva (1992, p. 2), a ênfase na importância da imagem "não pretende [...] localizar alguma força messiânica em tais fontes nem colocar o textual sob suspeição".

A própria definição de caricatura, charge e cartum é objeto de controvérsia. Para Cassio Loredano (apud LAGO, 1999, p. 10):

Nada é muito preciso. Charge e caricatura são a mesma palavra: carga; mas quando numa redação brasileira se diz charge, em geral se está pensando na sátira gráfica a uma situação política, cultural etc. estritamente atual; caricatura é geralmente sinônimo de portrait-charge; e cartum vale para o comentário satírico duma situação independente da atualidade.

Já para Chico Caruso (apud LAGO, 1999, p.11), o critério é espacial: 
[...] uma cena de horizonte amplo seria um cartum; centrada numa situação ou em personagens definidos seria uma charge, e focada exclusivamente numa pessoa, uma caricatura. Mas "caricatura" é ainda o termo genérico que se aplica no Brasil ao desenho de humor em geral.

Em sua revisão bibliográfica sobre o conceito de caricatura e charge, Alberto Gawryszewsky (2008, p. 24) aponta a dificuldade de encontrar um conceito definitivo, especialmente para as caricaturas e charges políticas, e propõe a criação de novos conceitos, "tais como caricatura ideológica e charge ideológica. Imagens estas mais voltadas ao embate ideológico, de defesa de um ideal político, de transformações políticas, econômicas e sociais”. Embora a busca pelo rigor conceitual seja interessante, não utilizaremos, aqui, o conceito de charge ou desenho político, pois todo desenho é político em sentido amplo, embora nem todo desenho seja oriundo de um partido político.

Na análise de imagens, a reconstrução de séries é um procedimento metodológico importante. Sergio Miceli (1996, p. 142), ao analisar os retratos da elite brasileira, destaca que a opção de privilegiar "séries iconográficas em diferentes recortes, em lugar da apreciação de trabalhos isolados, foi se revelando uma estratégia metodológica rentável para um número expressivo de obras". Embora a tipologia da documentação seja diferente, esse procedimento tem sido utilizado por vários autores que têm por foco específico os desenhos. Rodrigo Patto Sá Motta (2006, p. 11) seleciona os temas que estruturam os capítulos de seu livro com base na incidência, privilegiando os mais recorrentes, que permitem perceber "as linhas mestras do debate político [...] O fato de certos temas terem sido objeto de repetição e reiteração [...] ajuda a revelar o eixo central das polêmicas e críticas ao governo". Genny Abedelmalack (1991) também agrupa as caricaturas que analisa por incidência temática: café, voto etc. Já Alberto Gawryszewsky (2004, p. 107), ao analisar desenhos comunistas, afirma que "a quantidade produzida deste material é enorme" e interroga "qual o tema a estudar? Qual deixar de fora? Qual imagem escolher? Qual representava melhor a mensagem passada? Qual associava mais de um tema?". Questão que também perpassa trabalhos internacionais, pois, ao estudar os pôsteres chineses, Harriet Evans e Stephanie Donald (1999, p. 9) 
questionam se essas fontes devem ser analisadas pelos aspectos políticos, estéticos, qualidades formais, pelo período de produção etc.

Evidentemente, as imagens estão abertas a múltiplas interpretações. Christie Davies (2011, p. 94), discutindo de modo geral o significado nos cartuns e a relação entre a intenção do caricaturista e a interpretação do leitor, pondera que "o ponto de vista do cartunista sobre a sua criação é importante, embora, é claro, não seja definitivo. Estamos em uma área onde os significados são escorregadios”. E Alberto Manguel (2001) finaliza seu instigante livro afirmando que

[...] essencialmente, toda imagem nada mais é do que uma pincelada de cor, um naco de pedra, um efeito de luz na retina, que dispara a ilusão da descoberta ou da recordação [...] De todo modo, tais reduções não oferecem explicações nem pistas sobre o que se constela em nossa mente quando vemos uma obra de arte que, implacavelmente, parece exigir uma reação, uma tradução, um aprendizado de algum tipo - e talvez, se tivermos sorte, uma pequena epifania. Essas coisas parecem estar além do alcance de qualquer livro, e com certeza deste, feito de notas ao acaso e de indecisões.

\section{Getúlio Vargas}

O personagem mais importante do Brasil no século XX é Getúlio Vargas, que marca a vida nacional de maneira decisiva. Desse modo, não surpreende sua presença na iconografia comunista como principal adversário do partido. Lima (1963) considera Dom Pedro II e Getúlio Vargas, pelo tempo que estiveram à frente do país, os dois personagens mais visados pelos desenhistas. Tanto em quantidade como em assiduidade, ele, sem dúvida, é o inimigo fundamental do PCB. Embora os comunistas por vezes o tenham apoiado e sua trajetória apresente momentos de aproximação com Luiz Carlos Prestes, Getúlio Vargas foi representado, de certa forma, como a antítese de Prestes na iconografia comunista.

O primeiro dado biográfico que os aproxima é o Estado de origem, o Rio Grande do Sul. Amado (1979, p. 1) inicia a obra O Cavaleiro da Esperança, de 1942, biografia laudatória de Prestes, destacando o cenário dos pampas gaúchos, para salientar que 
aquela terra formou caudilhos e revolucionários, não sendo difícil imaginar a quem se referia.

As vidas de ambos se cruzam em muitos momentos. Ao começar com a busca de Getúlio Vargas pelo apoio de Prestes durante a Revolução de 1930, depois a tentativa de Prestes de derrubar Vargas em 1935; a consequente prisão de Prestes e o envio de sua mulher para os campos de concentração nazistas; o apoio prestista à entrada do Brasil na guerra; o queremismo; as críticas à volta de Vargas à presidência; por fim, o suicídio deste e a retomada do contato com os trabalhistas. Todos esses momentos são marcados por combates quase permanentes e aproximações táticas.

A campanha pelo retorno de Getúlio Vargas à presidência encontrou a oposição dos comunistas, que relembraram a eleição do general Eurico Gaspar Dutra. O Ministro da Guerra varguista, após depor o presidente e encerrar o Estado Novo, só venceu a eleição com o apoio do presidente deposto. O slogan "Ele disse: vote em Dutra" foi o endosso fundamental para que os trabalhadores e o Partido Trabalhista Brasileiro (PTB) apoiassem o candidato.

A imprensa comunista recria o "ele disse" com outra conotação, comparando com o que "ele fez". Um desenho de Quirino Campofiorito mostrava o passado de Getúlio no Estado Novo, formado pelos monstros Tribunal de Segurança Nacional, Departamento de Imprensa e Propaganda (DIP) e Polícia Especial, todos maiores que Getúlio e o acompanhando como capangas (o que o burocrata da Justiça perde em estatura e truculência para seus acompanhantes ganha em ferocidade). O desenho foi publicado em Voz Operária, de 5 de agosto de 1950, com uma legenda sobre a "tirania do sanguinário" Vargas, remetendo, então, ao tribunal de exceção, à censura e à repressão. A legislação social criada pelo ditador não entrava nessa representação, só os monstros, que reforçavam e justificavam suas características autoritárias e desmistificavam a ideologia estadonovista (Figura 1). 


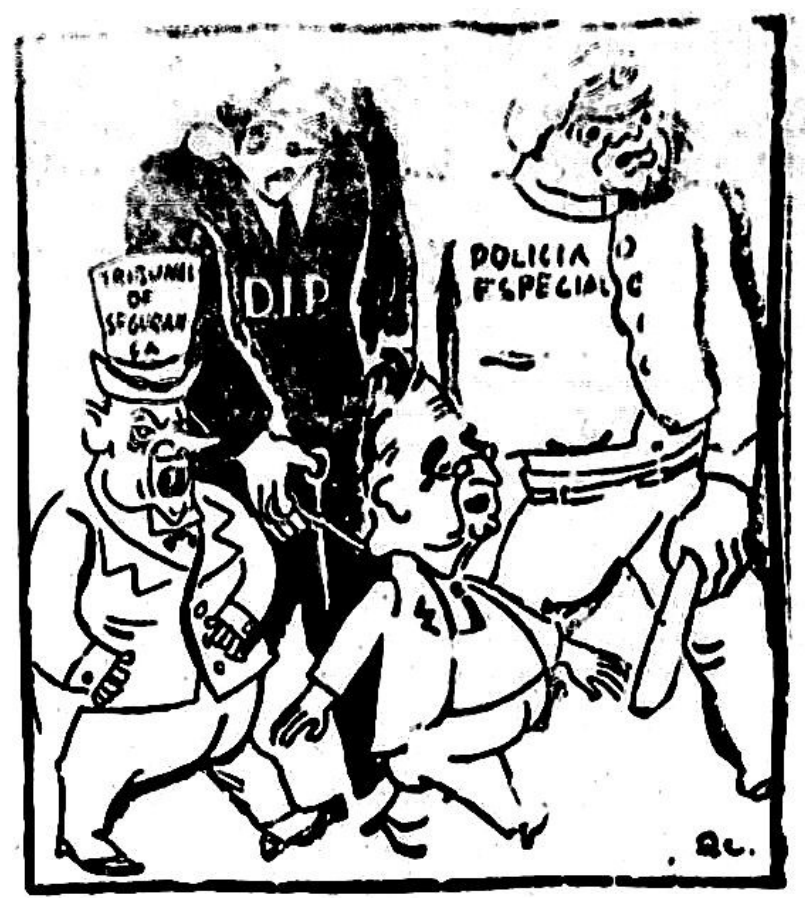

Figura 1: Voz Operária de 5 de agosto de 1950, p. 11.

Legenda: Assim foi a tirania do sanguinário Getúlio Vargas: polícia contra a classe operária e o povo a mais feroz justiça de classe contra os que lutavam pela libertação nacional e amordaçamento da imprensa livre (sic).

Fonte: Cedem/Unesp. http://www.cedem.unesp.br/

O mesmo Voz Operária, de 2 de setembro de 1950, na última página, (Figura 2) coloca um velho Vargas em pé na cadeira da tribuna do Senado falando ("Ele disse") em defesa do Estado Novo, comparando com o que "Ele fez". Seu mau hálito é símbolo da decadência e afasta o microfone. No restante da página, o jornal enumera as injustiças daquele regime. É fundamental o "ele disse", porque remete à propaganda do rádio, tanto no tempo do Estado Novo como na tribuna do Senado, ou ainda aos seus discursos em diversas manifestações, um elo forte com a massa. Ao exibir um microfone animado, que recua diante do hálito cadavérico, o desenho mostra como a mensagem de Getúlio está apodrecida: é a voz do passado, da morte. Não por acaso, aparece um enrugamento e a redução de sua garganta, o que chama a atenção do leitor, mostrando a fraqueza de sua mensagem, com o presidente próximo de ficar afônico. O microfone se afasta, mas, para o partido, é a metáfora da massa dos trabalhadores se afastando do ditador. Para completar o quadro, ele é um anão que precisa subir na cadeira para alcançar o microfone. Com algumas variações, essa representação varguista apareceu em diversos momentos. 


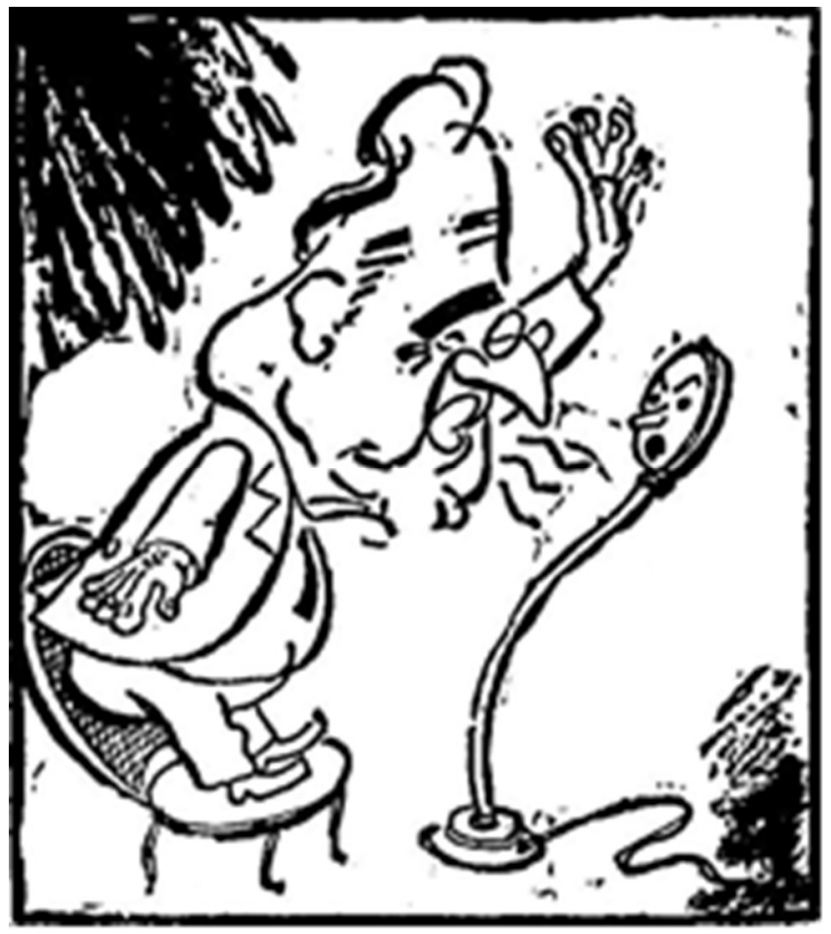

Figura 2: Voz Operária de 2 de setembro de 1950, p. 12. Fonte: Cedem/Unesp. http://www.cedem.unesp.br/

Essas imagens do partido comunista relembram e desmistificam a propaganda e a ideologia do Estado Novo, estas já objeto de estudos historiográficos importantes (CAPELATO, 1998; LENHARO, 1986), desenhando o político que retorna de seu refúgio em São Borja-RS como velho, decrépito e em decadência.

A vitória eleitoral de Getúlio Vargas na campanha à presidência, em 1950, e o retorno ao Catete nos "braços do povo", fizeram com que o PCB precisasse lidar com um inimigo conhecido. Dentre os aspectos ressaltados pelos desenhos comunistas estão a caracterização de grande fazendeiro no Rio Grande do Sul, as "realizações" durante o Estado Novo, o "trabalhismo" (citado entre aspas na imprensa comunista), e, como é característico na descrição dos políticos adversários, sua submissão aos interesses norteamericanos.

Uma das imagens recorrentes sobre Vargas o caracteriza como fazendeiro de charuto, chicote e espora, sendo repetida em diversos momentos sem relação com as matérias da mesma página. Em Voz Operária, de 12 de janeiro de 1951 (Figura 3), por exemplo, fuma charuto, com olhos que não podem ser vistos, sem sabermos para onde 
olha. De acordo com García (1980, p.696), o chicote "serve para castigar e exercitar os cavalos", mas o cavalo não aparece na imagem, o que leva a crer que o chicote, aqui, é usado como "símbolo do poder judiciário e de seu direito de infligir castigos", como citado por Chevalier e Gheerbrant (2003, p.233). O chicote de Vargas não se volta contra cavalos, mas, sim, contra os trabalhadores, o que mostra seu poder de latifundiário, de explorador. Ele tem em mãos o Poder Judiciário, apanágio do Estado, podendo infligir castigos aos trabalhadores. O chicote também pode ser uma referência aos açoites do tempo da escravidão.

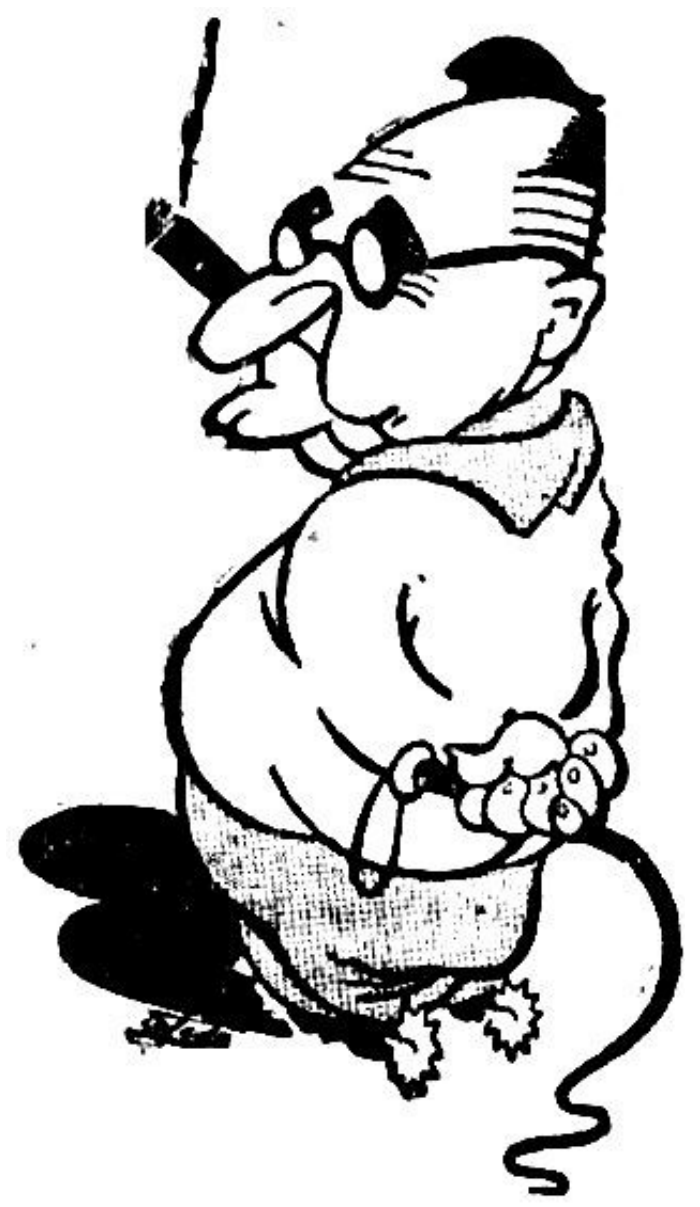

Figura 3: Voz Operária de 12 de janeiro de 1951, p.9. Fonte: Cedem/Unesp. http://www.cedem.unesp.br/

Com essas características, o partido constrói a imagem de uma figura de personalidade autoritária desde os tempos de fazendeiro latifundiário em São Borja-RS. O jornalista Wainer (1988), ao visitá-lo no retiro gaúcho, afirmou que era chamado de "o chefe" e ficou surpreso ao vê-lo, já que parecia literalmente um boneco gaúcho. 
A revista Fundamentos, de 20 de julho de 1951 (Figura 4), publica um desenho que segue a mesma linha, porém, dessa vez Vargas não tem um chicote, mas, sim, uma corda, utilizada literalmente para laçar um agricultor em vez de gado, o que revelaria o tratamento dispensado aos seus funcionários e, por extensão, a todos os trabalhadores do país. Provavelmente, o objetivo seria negar um dos grandes lemas do "pai dos pobres": o de que o governo, a partir de 1930, parou de tratar a questão social como um caso de polícia, tempos em que o trabalhador, muitas vezes, era preso no laço, assim como o Getúlio da charge fazia em seus domínios no Sul.

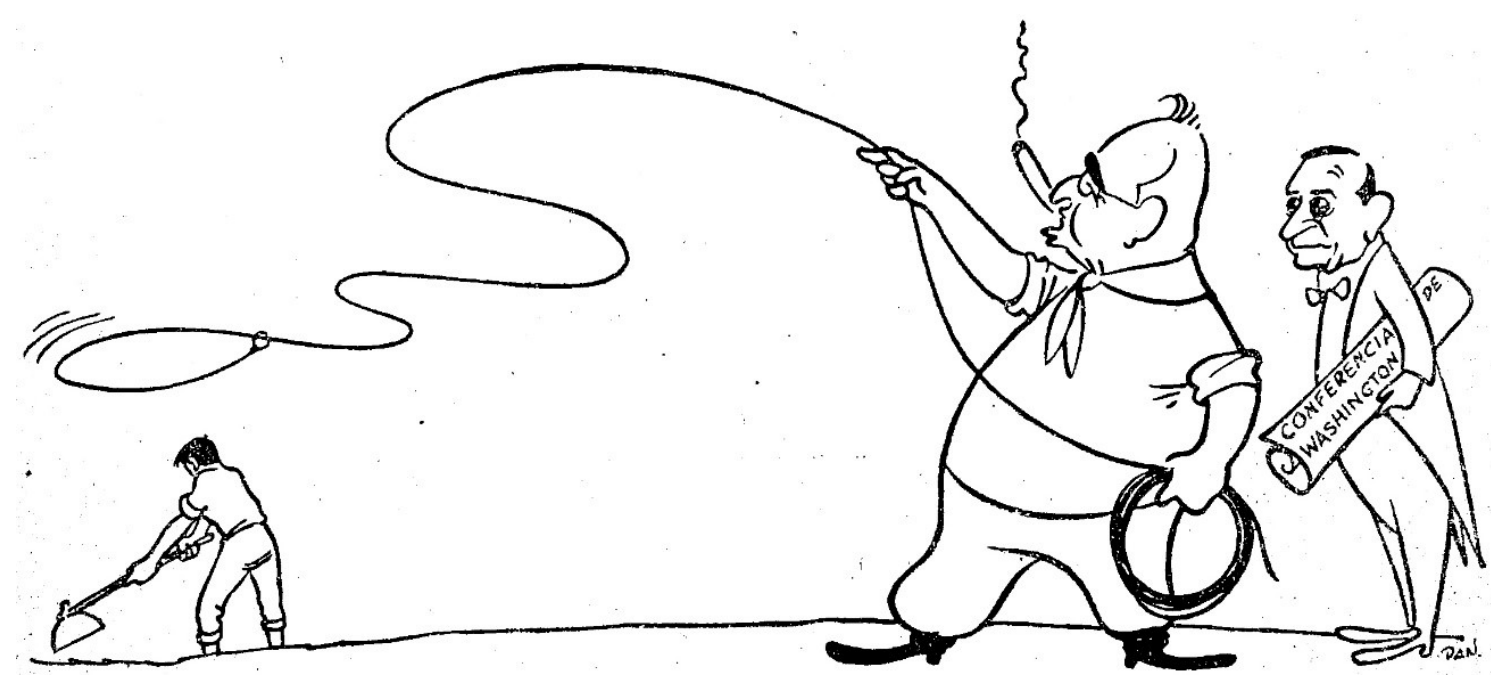

Figura 4: Fundamentos de 20 de julho de 1951, p. 24. Fonte: Cedem/Unesp. http://www.cedem.unesp.br/

A espora também segue a mesma teia de significados. No sentido estrito, serve para o cavaleiro incitar o cavalo, agredindo-o para que obedeça ao cavaleiro. Todavia, “chamar, ou procurar, nas esporas, [no Brasil]" ou "dar de esporas [na região Sul]" significa "repreender, censurar", enquanto "acudir à espora”, figurativamente, significa “obedecer a vontade de alguém, ser dócil aos seus desejos”, de acordo com García (1980, p.1415). Amado (1979, p. 24), no romance sobre a vida de Prestes, descreve os tiranos que "partindo da sua fazenda, do chicote sobre os bois e a espora sobre os ginetes, haveriam de chicotear e esporear, humilhar, desonrar e desgraçar a raça brasileira”. Assim, a espora corrobora o sentido do chicote e do laço, já que também pode ser uma referência de poder contra os trabalhadores, transformados em montaria. 
Em Voz Operária, esse caráter subentendido anteriormente fica mais claro em uma charge intitulada "Os mediadores da greve em São Paulo", publicada abaixo de um editorial sobre $01^{\circ}$ de maio de 1953 (Figura 5), durante a greve dos 300 mil. Nela, vemos Vargas com espora, espada e porrete partindo para cima do trabalhador, auxiliado por um cangaceiro montado em um cavalo. Aqui, talvez exista uma referência sutil a um regionalismo, uma união de forças retrógradas e bem armadas, representadas por um gaúcho e uma figura típica do Nordeste que, covardemente, pois em maior número e pelas costas, agridem o operariado de São Paulo, que só conta com seus punhos para se defender.

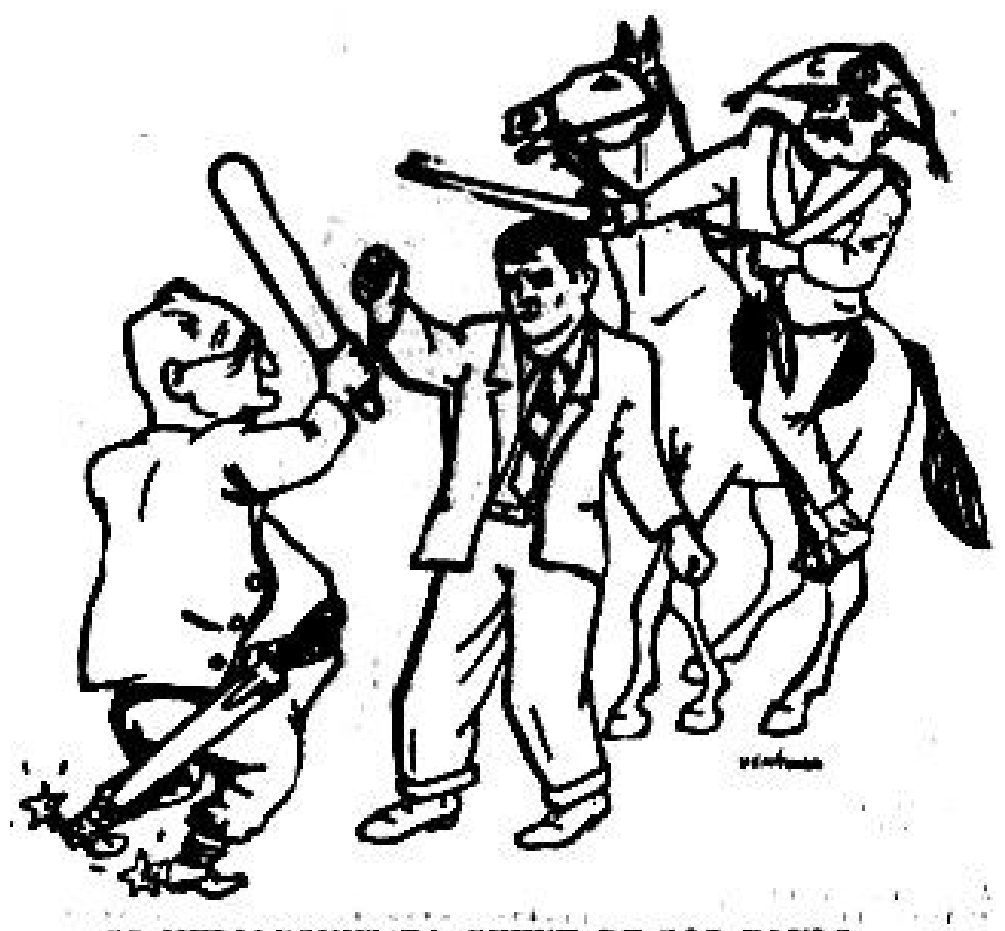

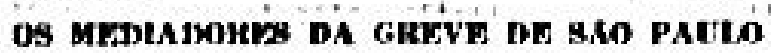

Figura 5: Voz Operária $1^{\circ}$. de maio de 1953, p.2. Fonte: Cedem/Unesp. http://www.cedem.unesp.br/

Essa imagem de Vargas "cavaleiro" faz um contraponto ao discurso sobre Prestes como Cavaleiro da Esperança. Voz Operária, de 9 de fevereiro de 1952 (Figura 6), mostra Vargas guiando cavalos, mas, aqui, a referência é a tradição cristã dos cavaleiros do apocalipse. Vargas puxa animais esquálidos montados por caveiras, cada uma trazendo uma desgraça: Peste, Fome, Guerra e Morte. Nessa imagem, ele está em decadência física, puxando as forças da crise, do atraso e da morte. Esse "cavaleiro do apocalipse" é 
o oposto da esperança representada por Prestes. A ideia de que Vargas vai trazer a desgraça também está presente na última página de Voz Operária, de $1^{\circ}$ de fevereiro de 1952 (Figura 7), onde dialoga com três monstros, a carestia, a tuberculose e o analfabetismo, males que o presidente prometera extinguir.

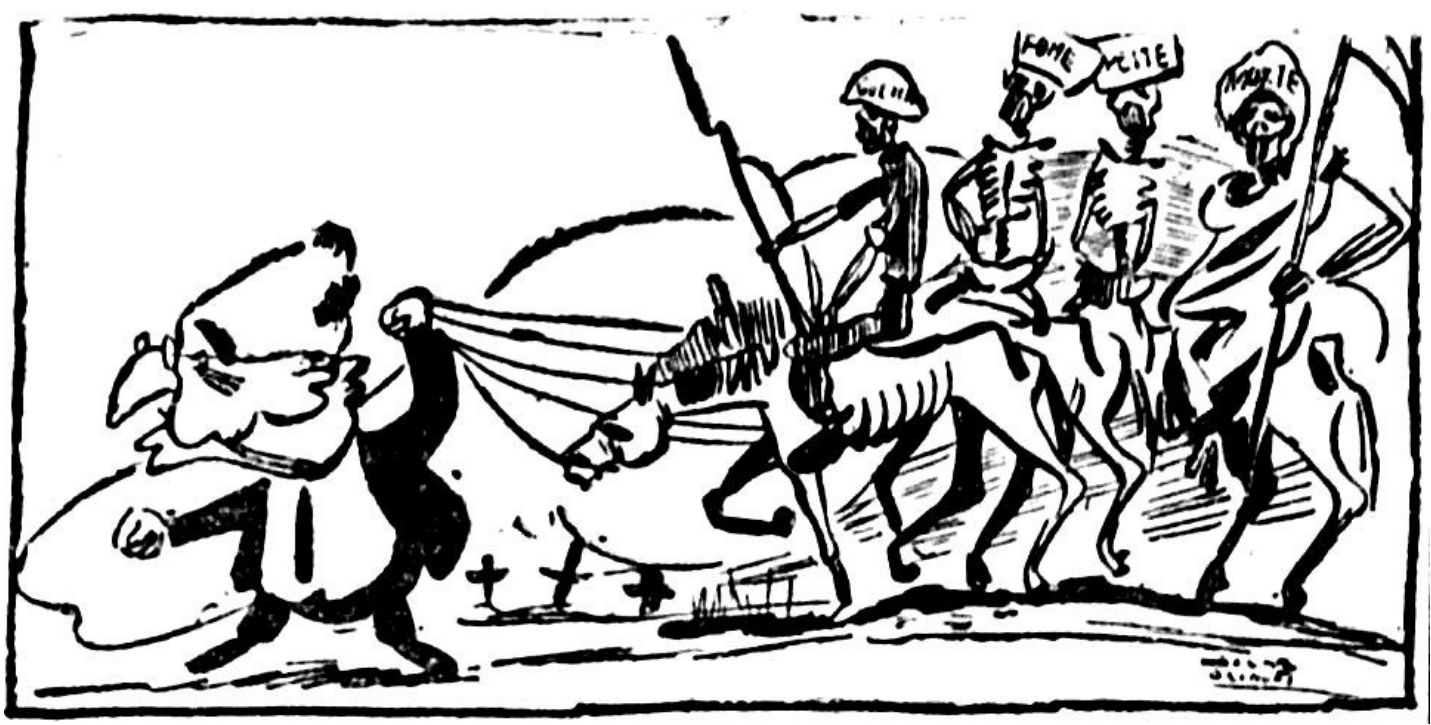

Figura 6: Voz Operária de 9 de fevereiro de 1952, p.3.

Fonte: Cedem/Unesp. http://www.cedem.unesp.br/

O "DESMEMMORIADO"

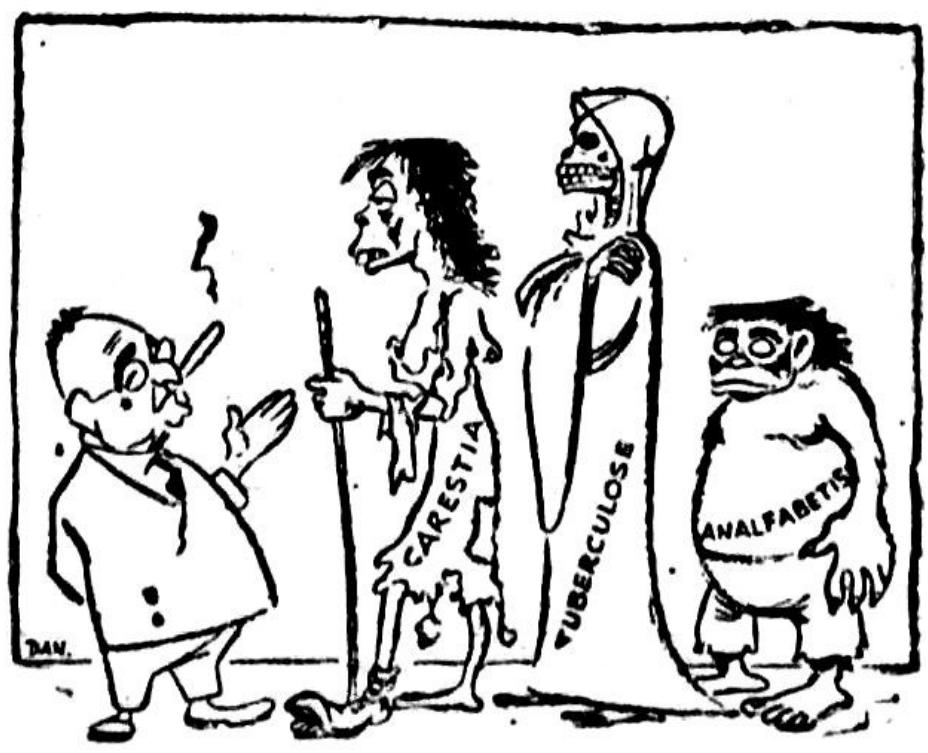

Hes - Voes nifo disme que In acabar conoweer.

Getullo - Eut Bu disese lase?

Figura 7: Voz Operária de $1^{\circ}$. de fevereiro de 1952, p.12.

Fonte: Cedem/Unesp. http://www.cedem.unesp.br/ 
Ainda como antítese do Cavaleiro da Esperança, foi publicado outro desenho na reportagem de página dupla "A oligarquia do boi no Rio Grande do Sul”, em Voz Operária, de 21 de novembro de 1953 (Figura 8). É interessante ressaltar que quando, efetivamente, Vargas monta um animal, a sela está atrelada ao boi, e não ao cavalo. A intenção, ao desenhá-lo dessa maneira, é aumentar a oposição com o Cavaleiro da Esperança, que monta um cavalo, mostrando o caminho para o povo, enquanto Getúlio monta um animal passivo e pronto para o abate, que simboliza o acúmulo de carne, poder e dinheiro (CANETTI, 1995), ambos guiados pelo abutre imperialista que indica o destino onde se alimentará de seus despojos. Vale salientar as associações entre dinheiro, comida, obesidade e poder: de certa maneira, o boi representa uma continuação do corpo de Vargas, tamanho seu poder, ganância e dinheiro.

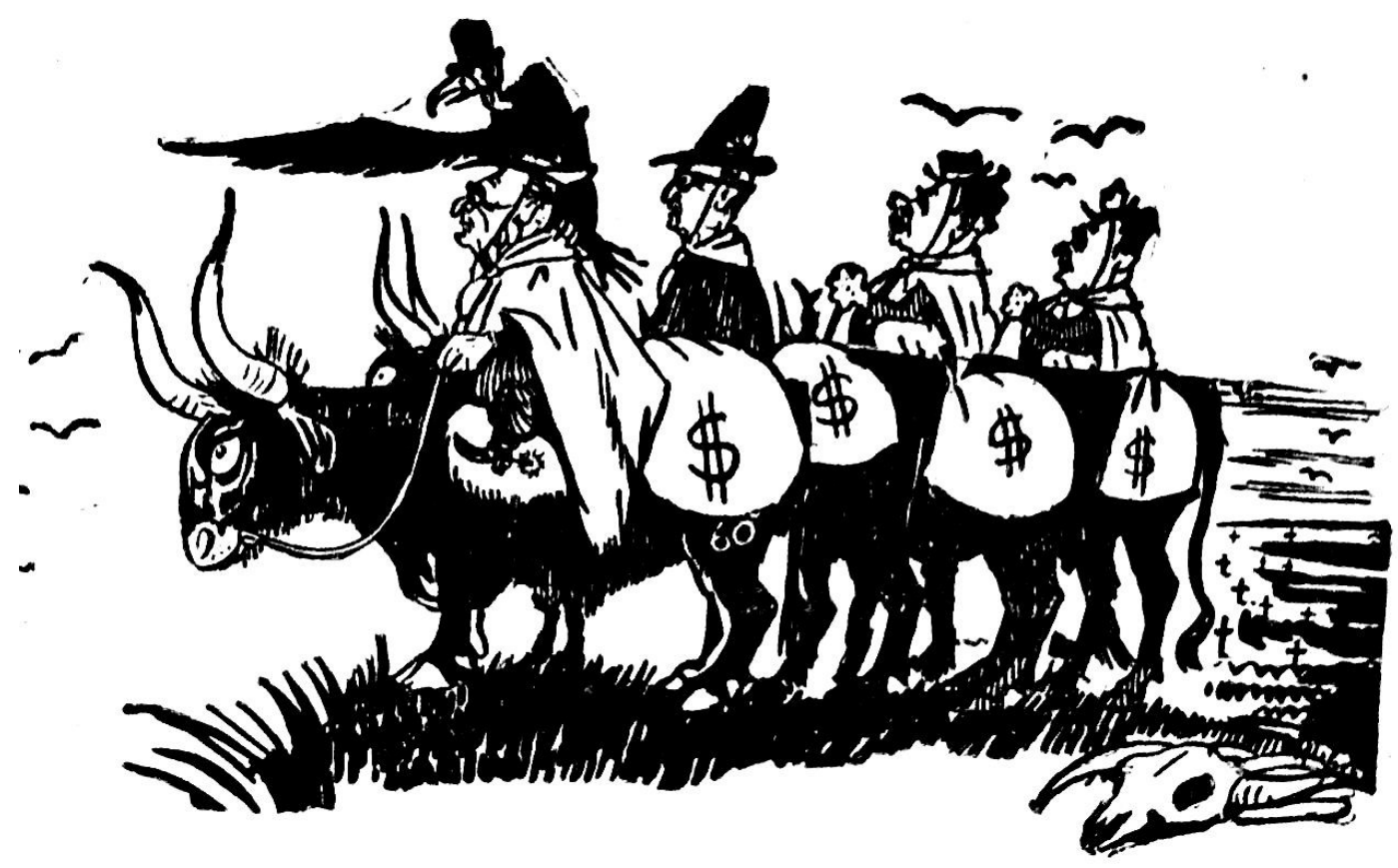

Figura 8: Voz Operária de 21 de novembro de 1953, p.7.

Fonte: Cedem/Unesp. http://www.cedem.unesp.br/

Ainda em relação ao boi, convém destacar que ele não tem os cornos cerrados, como ocorre usualmente para diminuir a agressividade e o risco de acidentes, mas, sim, chifres enormes, símbolo de poder. Uma análise mais contemporânea associa os cornos às forças regressivas, já que o diabo é representado de chifres e com os cascos fendidos (CHEVALIER e GHEERBRANT, 2003). Essas forças do atraso também são representadas 
pela direção que o grupo toma da direita para a esquerda, marchando para o passado. Algo diferente das representações de Prestes em seu cavalo que, predominantemente, caminha em direção ao futuro, para a direita ou para frente, no sentido do leitor. $O$ próprio fato de Vargas não aparecer cavalgando, enquanto Prestes surge na iconografia comunista montado no cavalo, mesmo que, verdadeiramente, usasse um jegue, tem relação com o fato de que cavalgar, como afirma Canetti (1995, p. 390), “dá sempre a impressão de não ser um fim em si mesmo, de que, cavalgando-se, pretende-se atingir uma meta, e atingi-la mais rapidamente do que seria possível de outra forma".

Nessa extensa reportagem, Getúlio é chamado de urubu-rei comandando uma oligarquia que, associada ao imperialismo americano, tem muita influência na política nacional e ganha a vida às custas da fome do povo. O animal desenhado não é o uruburei, ave mais graciosa, mas, sim, o animal comum, que reforça a ideia de regresso, já que vive da carniça, da morte. Na gíria, urubu é agente de empresa funerária (GARCíA, 1980) e vale ressaltar que há um bando dessas aves povoando o céu no rastro trilhado por essa oligarquia, sobrevoando um sutil amontoado de cruzes diminuídas pela distância, denotando um percurso de morte e destruição. Talvez o próprio crânio de um boi morto aos pés do grupo faça referência à seca no Nordeste, tema importante no período, e sobre o qual a imprensa comunista acusava Getúlio de ser omisso.

O próprio urubu tem ascendência sobre Getúlio, já que ele representa o imperialismo norte-americano, como se vê no chapéu com listras e estrelas. A reportagem inclui outro desenho central, em que Getúlio Vargas atua como carniceiro, porém, não mata bois, mas, sim, a população. O fazendeiro de São Borja caminha em direção ao leitor, sujo de sangue e empunhando uma faca, um machado e vestindo avental. Em vez dos alvos serem os animais que garantem sua riqueza, são os leitores, ou seja, os trabalhadores. O desejo de agressão está evidenciado no olhar alucinado de Vargas (Figura 9). 


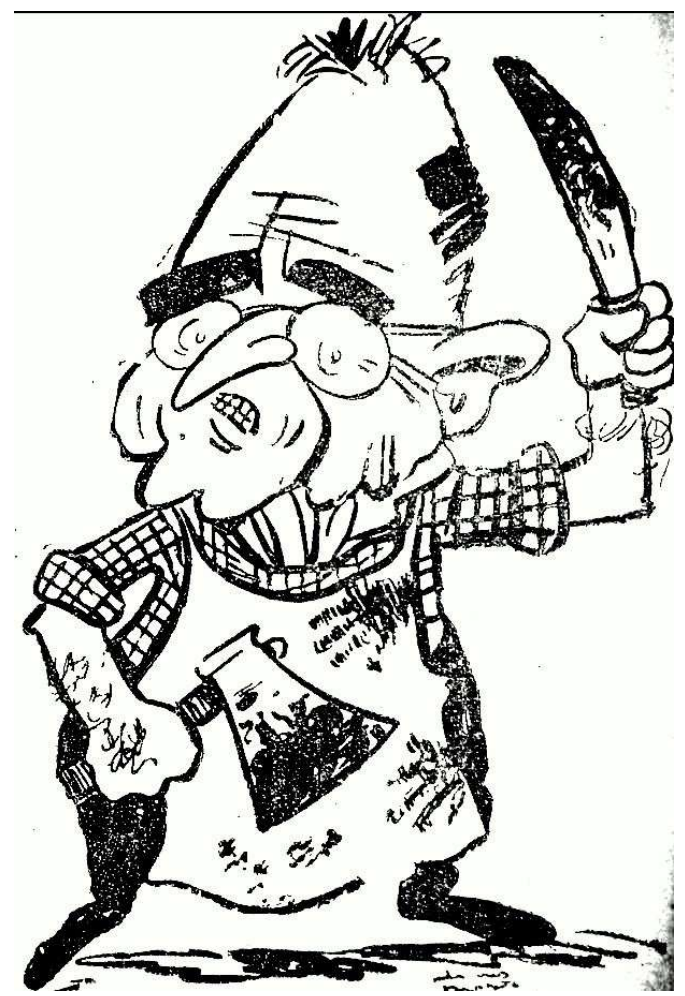

Figura 9: Voz Operária de 21 de novembro de 1953, p.6. Fonte: Cedem/Unesp. http://www.cedem.unesp.br/

Esse bando de "cavaleiros" da destruição, do atraso e do poder eram um contraponto ao da esperança de uma nova vida, Luiz Carlos Prestes, líder do PCB. Enquanto um encaminhava o país para a libertação, o outro guiava as forças do atraso, da ignorância e do poder corrompido. Vale abordar outra representação ligada a Vargas, a de gorila ou macaco. Motta (2007, p. 198) chama atenção para a relevância do gorila nos jornais de esquerda, ressaltando que esse símbolo "sugere um ser dotado de força maciça, brutal, mas, ao mesmo tempo - e aí reside parte do efeito cômico -, o animal evoca a ideia de rudeza, de ignorância. O gorila seria uma síntese de brutalidade e estupidez". O autor também nota que o símbolo mostra a percepção predominante na esquerda de que "à direita encontram-se as forças do atraso, da ignorância e da repressão" (MOTTA, 2007, p. 198).

Ao fazer um histórico dessa figura, Motta (2007, p. 198) destaca o fato do uso do gorila em caricaturas não ter sido criado no Brasil, tratando-se de importação da Argentina, onde a expressão "começou a circular em 1955, quando Perón experimentava momento de grande instabilidade política". Na origem, fazia referência aos militares de direita golpistas, mas, com o tempo, passou a representar o conjunto das forças de 
direita. Embora a influência do debate político argentino possa ter contribuído para a disseminação, havia na imprensa comunista algumas representações anteriores em que a figura do símio fora utilizada.

Na capa de Notícias de Hoje, de 4 de agosto de 1954 (Figura 10), Getúlio Vargas surge como um macaco, em um desenho sem relação com as notícias ao redor. Com a legenda "Mac Carthy, Mac Arthur, Mac Kaco", o desenhista coloca os dois membros do imperialismo norte-americano levando armas (bomba atômica e metralhadora), enquanto Vargas imita ambos, mas de maneira prosaica, com uma espingarda de brinquedo que dispara rolha. Aqui, a representação do macaco também está relacionada ao verbo macaquear, que segundo García (1980), significa imitar os costumes, os trajes, os hábitos, os enfeites, as comidas dos outros, especialmente dos estrangeiros. A submissão de Vargas ao imperialismo norte-americano era tamanha que ele acaba por imitar o comportamento dos estrangeiros, caminhando para a guerra.

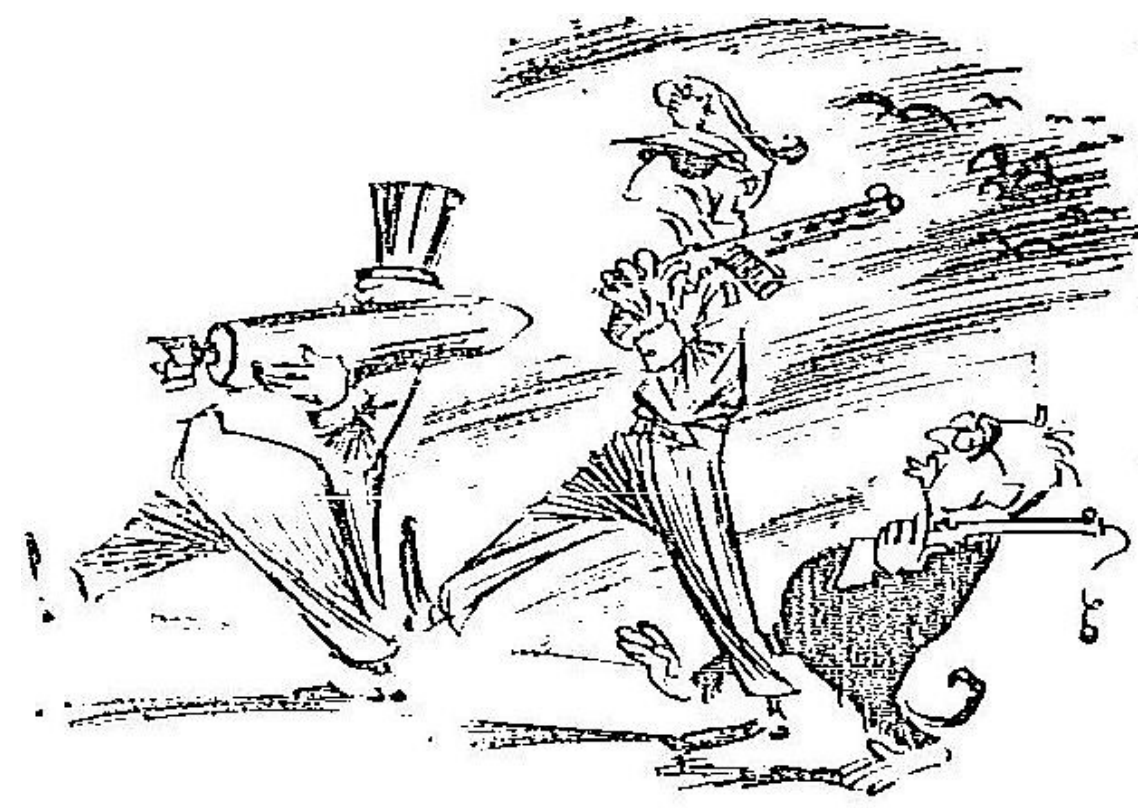

\section{Plic Garthy, Mac Arthur, Mac Kaco}

Figura 10: Notícias de Hoje de 4 de agosto de 1954, p.1. Fonte: Cedem/Unesp. http://www.cedem.unesp.br/

Chamar Getúlio de “Mac Kaco”, brincando com o som da palavra, também reforça a ideia de que Vargas é decadente por ser uma "pessoa doente ou velha", um "caco" (García, 1980), na expressão popular. A utilização de um Vargas zoomórfico também faz 
referência à evolução humana, de macaco a homo sapiens, associando-o a um estado primitivo. Ainda nesse desenho, há uma reconstrução iconográfica da evolução da espécie humana, ou melhor, da involução dos poderosos, já que os três caminham em direção à esquerda, ao passado. O sentido da "regressão" dos personagens é dado também pela referência às armas, da mais primitiva, na mão de Vargas, até a mais poderosa, na mão de Mac Carthy, ou seja, aprimoram a arte de matar: esse é o caminho trilhado por essa classe decadente que exerce o comando do mundo.

Na última página de Voz Operária, de $1^{\circ}$ de março de 1952 (Figura 11), exibe Getúlio em cima de uma jaula ao lado de dois burgueses, pronto para soltar a fera fascista, um gorila. Com a chave na mão, ele aparece pronto para utilizar o fascismo, essa forma regressiva de organização social, para dar um golpe. O animal estava controlado na jaula e é Getúlio que tem a "chave" para libertar essa fera e desencadear um novo golpe, um "terror fascista", como coloca a reportagem. Entretanto, mesmo sendo o detentor da chave, Getúlio aparece cercado de gordos burgueses, bem maiores do que ele, e aos quais parece subserviente, já que um lhe dá instruções, enquanto o outro repousa a mão em seu ombro, em sinal de controle e superioridade. Acima do desenho, a manchete afirma: "Plano de provocações e de terror fascista".

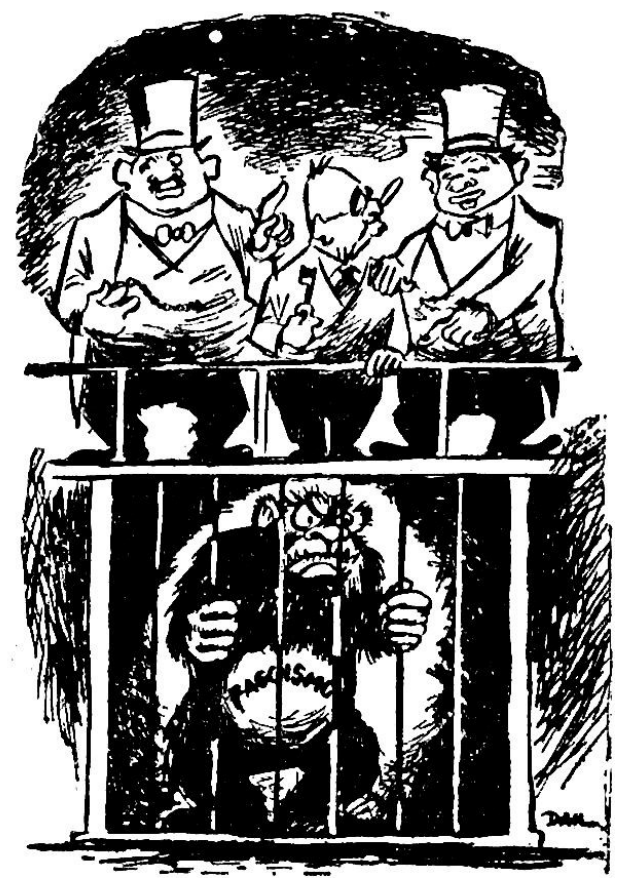

Figura 11: Voz Operária de $1^{\circ}$ de março de 1952, p. 12. Fonte: Cedem/Unesp. http://www.cedem.unesp.br/ 
Ao ler a realidade da década de 1950 no contexto da Segunda Guerra, que marcou profundamente a identidade do próprio PCB, o partido se perde ao ver e mostrar para o trabalhador quem realmente "criava" o gorila.

Com as forças contrárias ao presidente articulando um golpe, os desenhos comunistas insistem na representação de Getúlio como golpista. O chargista Ramiro, de Notícias de Hoje, desenha na primeira página do jornal de 26 de fevereiro de 1954 (Figura 12) o presidente solicitando a um militar que coloque em funcionamento o "Robot" da reação, de nome "golpe de estado" e com o símbolo da suástica no peito. O tema não consta das reportagens da página do jornal. A escolha do militar como executor do plano mostra a crença de que Vargas teria o apoio do exército em um possível golpe, o que remete mais uma vez ao contexto estadonovista. O destempero de Getúlio que, de braços ao alto, fala em "única salvação" mostra a esperança do PCB de que o robô poderia falhar, o próprio militar parece não conseguir colocar a máquina em ação: os braços dele continuam estáticos.

\section{$O$ ¿ROBOT》DA REAÇÃO}

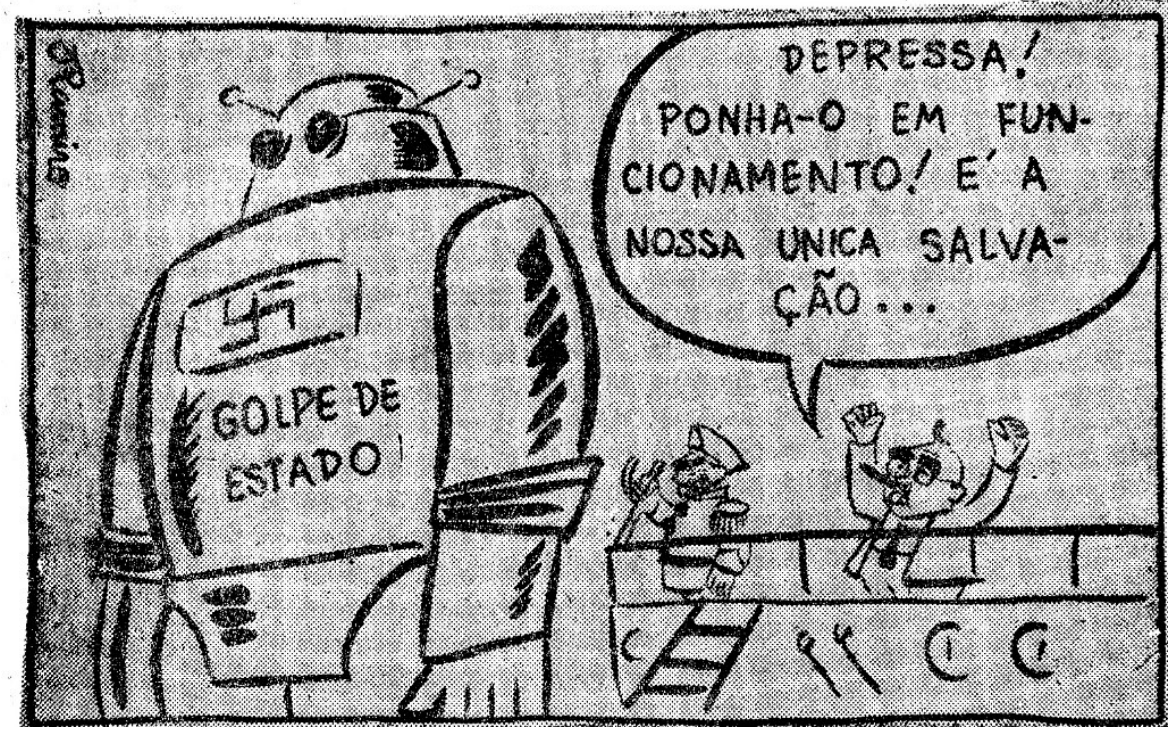

Figura 12: Notícias de Hoje de 26 de fevereiro de 1954, p.1. Fonte: Cedem/Unesp. http://www.cedem.unesp.br/

Desconstruir a atuação de Vargas no Estado Novo e seu discurso era fundamental para o partido, tendo em vista que a construção ideológica de Vargas como "pai dos pobres" o aproximava dos trabalhadores urbanos, alvo preferencial do PCB. O 
PCB na disputa eleitoral, sindical e simbólica.

Na última página de $A$ Classe Operária, de $1^{\circ}$ de setembro de 1951 (Figura 13), o partido critica a política “trabalhista”. O desenho, sem relação com as matérias da página, mostra Getúlio puxando uma corda presa a uma roldana trazendo os salários para baixo, enquanto o preço dos produtos sobe; do outro lado, o trabalhador usa a força na tentativa de inverter a situação. O conflito fica focado na classe operária versus Vargas, que produz a carestia. Em destaque na capa de Voz Operária, de 9 de fevereiro de 1952 (Figura 14), que faz um balanço do primeiro ano do governo Vargas, novamente a palavra "trabalhismo" aparece entre aspas, com o mesmo sentido: essa bandeira ideológica mostrada por Getúlio Vargas aos operários esconde seu olhar sorrateiro aos tubarões e ao presidente americano Harry Truman, destinatários dos recursos oriundos do trabalho do povo brasileiro.

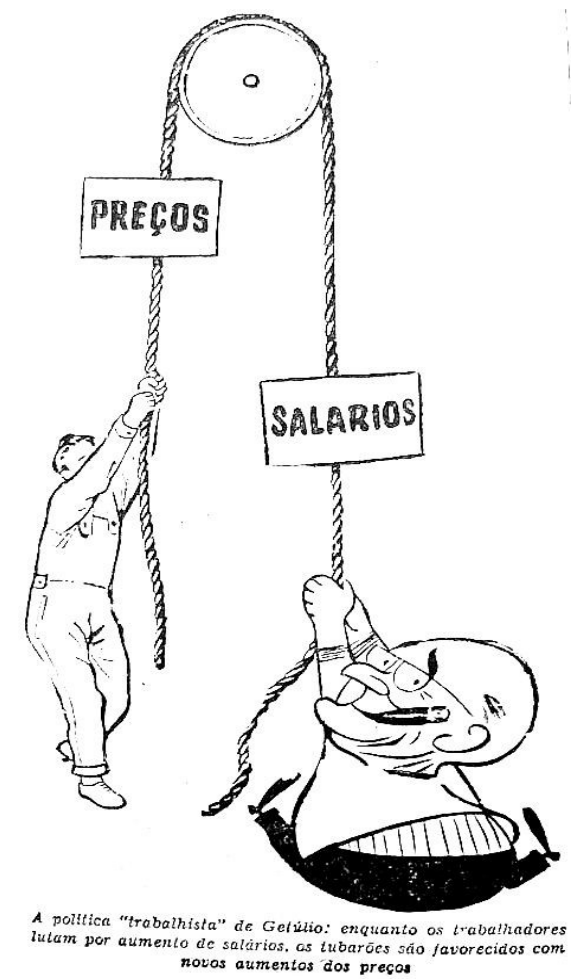

Figura 13: A Classe Operária de $1^{\circ}$ de setembro de 1951, p.6. Fonte: Cedem/Unesp. http://www.cedem.unesp.br/ 


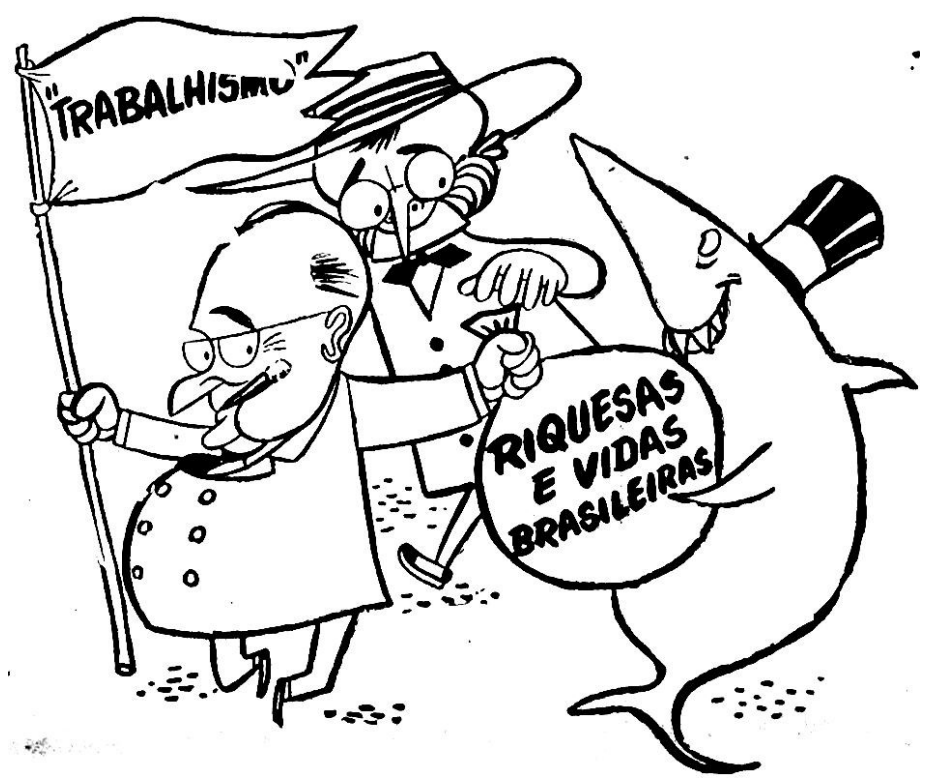

Figura 14: Voz Operária de 9 de fevereiro de 1952, p. 1. Fonte: Cedem/Unesp. http://www.cedem.unesp.br/

Essa associação entre imperialismo e os presidentes brasileiros, mostrados como submissos ou controlados por líderes americanos, pelo Tio Sam, pelos chefes do Departamento de Estado norte-americano etc., é constante na iconografia comunista (GAWRYSZEWSKY, 2004). Getúlio Vargas aparece como submisso inúmeras vezes: cumprimentando com um aperto de mão e um sorriso um representante da Standard Oil, em 8 de setembro de 1951, 2 de junho de 1951 e 12 de abril de 1954; como marionete de Truman, em 9 de fevereiro de 1952; sendo regido por um maestro americano e seguindo sua pauta, em 5 de julho de 1952; servindo como baqueta para o imperialismo tocar o bumbo em defesa do envio de tropas para a Coreia, de 5 de julho de 1952; como um cão correndo atrás de moedas americanas, em 9 de agosto de 1952; quase como um boneco de ventríloquo norte-americano, em 29 de novembro de 1952; como um brinquedo em miniatura dos americanos, em 10 de janeiro de 1953, todos do Voz Operária; como portavoz dos americanos em Imprensa Popular, de 8 de março de 1953; como a ponta de um aríete comandado pelos americanos, em 13 de março de 1953; membro de "sinistra orquestra" em que os instrumentos são armas sob a regência de um militar norteamericano em Voz Operária, de 11 de abril de 1953; como marionete, em 26 de abril de 1953 em Notícias de Hoje; vestido como norte-americano em Voz Operária, de 9 de maio de 1953; como animal de tração do Tio Sam em Voz Operária, de 16 de maio de 1953; em marcha junto com outros políticos sob a direção do Tio Sam em Voz Operária, de 3 de 
outubro de 1953; como uma prostituta jogada aos pés do Tio Sam em Notícias de Hoje, de 7 de fevereiro de 1954; comandando uma marcha de carnaval como Pierrô com um “estandarte" irônico "Standard and light boys" em Voz Operária, de 6 de março de 1953; com a bandeira americana na mão em Voz Operária, de 27 de março de 1954 e 26 de junho de 1954; com bandeira americana na mão e, literalmente, na mão do tio Sam em Notícias de Hoje, de 18 de abril de 1954, e como macaco de realejo em Voz Operária, de 21 de agosto 1954. O intuito desta relação é destacar a permanência da visão de Vargas como submisso aos interesses norte-americanos em um período no qual a pressão de setores golpistas nacionais e internacionais contra o governo era crescente.

Inicialmente, há a caracterização mais clara de que o interesse norte-americano no Brasil é puramente financeiro. Nessa linha de construção do personagem, um Getúlio suado aparece apertando uma prensa, esmagando os trabalhadores com as medidas e políticas governamentais, em Voz Operária, de 6 de dezembro de 1952 (Figura 15), desenho incluído abaixo do editorial "Organizemos a luta contra a carestia”. Exausto pela força empreendida, Getúlio pede ajuda financeira ao presidente Eisenhower, já que não há como extrair nada mais dos trabalhadores explorados.

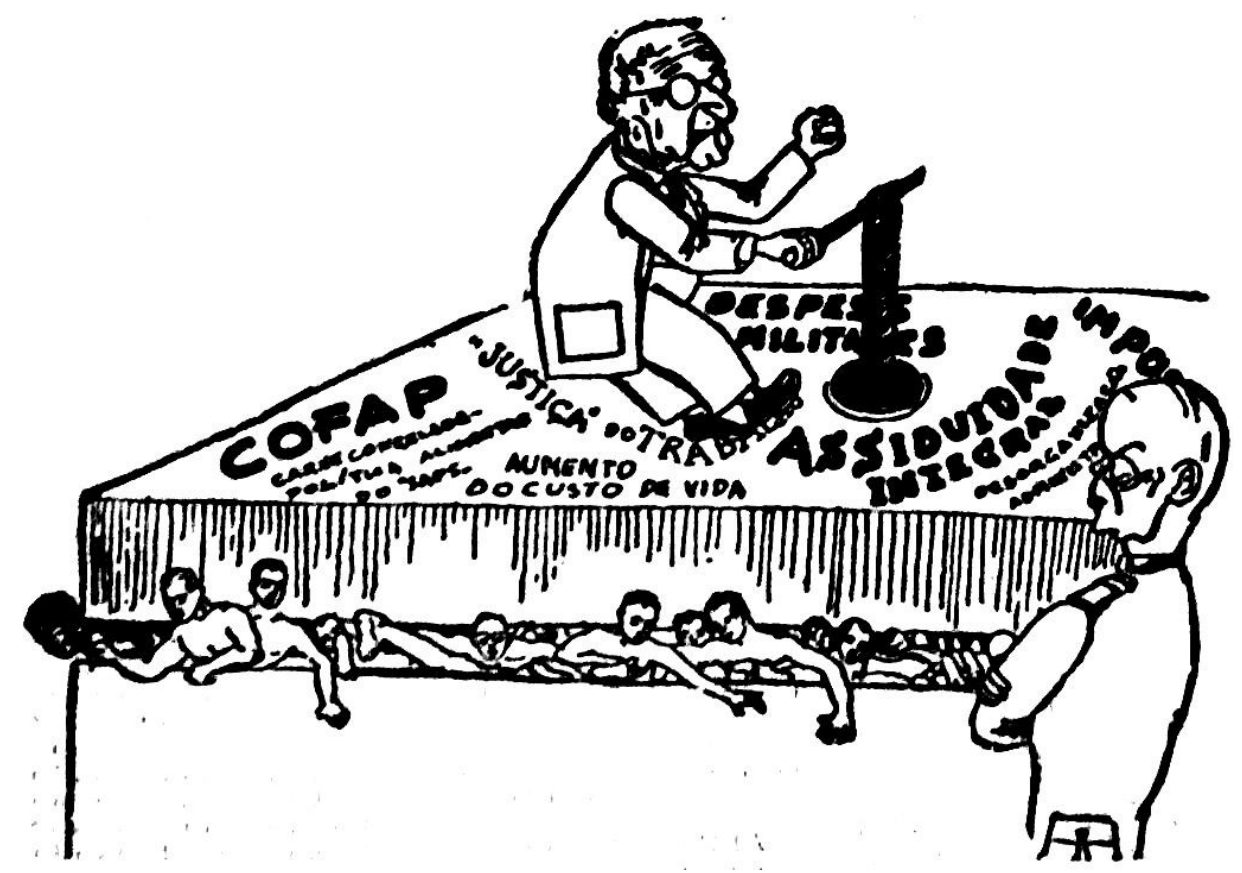

Figura 15: Voz Operária de 6 de dezembro de 1952, p.2. Legenda: Dada a pequena compressibilidade do consumo... Impõe-se o financiamento externo... (Da carta secreta de Getúlio Vargas ao Departamento de Estado) Getúlio a Eisenhower - Chefe, não há mais o que comprimir e eles acabarão rebentando a prensa. Mande mais dólares...

Fonte: Cedem/Unesp. http://www.cedem.unesp.br/ 
Outra caracterização de Getúlio era a de entreguista, um governante que oferece as riquezas nacionais ao estrangeiro. A palavra entreguista esconde o processo de produção envolvido na atividade econômica sugerida, seja ela qual for. Nunca aparecem os recursos técnicos e os investimentos realizados no Brasil para a extração de quaisquer matérias-primas, os desenhos enfatizavam somente estas sendo "roubadas" pelo imperialismo.

A ênfase é quase absoluta no imperialismo norte-americano, majoritariamente representado pelo Tio Sam, que aparenta ser quase onipresente na economia brasileira. Essa simplificação visava a despertar os trabalhadores para a questão do comércio assimétrico com os EUA, as consequências políticas do que estava sendo comercializado e qual seria o destino dos produtos. Dentre as representações que exploram essa característica, vale ressaltar a de garçom, como Getúlio é caracterizado em Voz Operária, de 2 de agosto de 1952, cuja função não envolve a fabricação efetiva de algum produto (nenhum trabalho, portanto), mas, sim, "servir" algo. Aqui, a relação de submissão da palavra "servir" fica evidente, também reforçada pela expressão bandeja: “dar de bandeja" significa dar não esperando algo em troca, exatamente o que Getúlio Vargas fazia ao servir a um ávido norte-americano. A questão mais importante talvez seja o que ele serve, o que entrega de bandeja. Nesse desenho, serve ao americano petróleo, tropas e, aparentemente, algum minério.

Vargas está mais bem caracterizado como garçom em Voz Operária, de 23 de janeiro de 1954 (Figura 16) e em 24 de julho de 1954, no mesmo jornal, embora com legendas diferentes. $\mathrm{O}$ americano continua ávido à espera das riquezas nacionais, mas, aqui, a caracterização de Getúlio como garçom é mais trabalhada, tanto no uniforme como no pano que ele traz, possivelmente para conter a salivação do norte-americano. $O$ prato servido é a pátria brasileira, já que a comida assume a forma do território brasileiro, ao mesmo tempo que se destaca dele o petróleo, representado pelas torres, e as tropas brasileiras. A gordura dos poderosos estava diretamente relacionada a "comer" a pátria brasileira, suas riquezas e potencialidades. 


\section{Getúlio Visto Por Stassen}

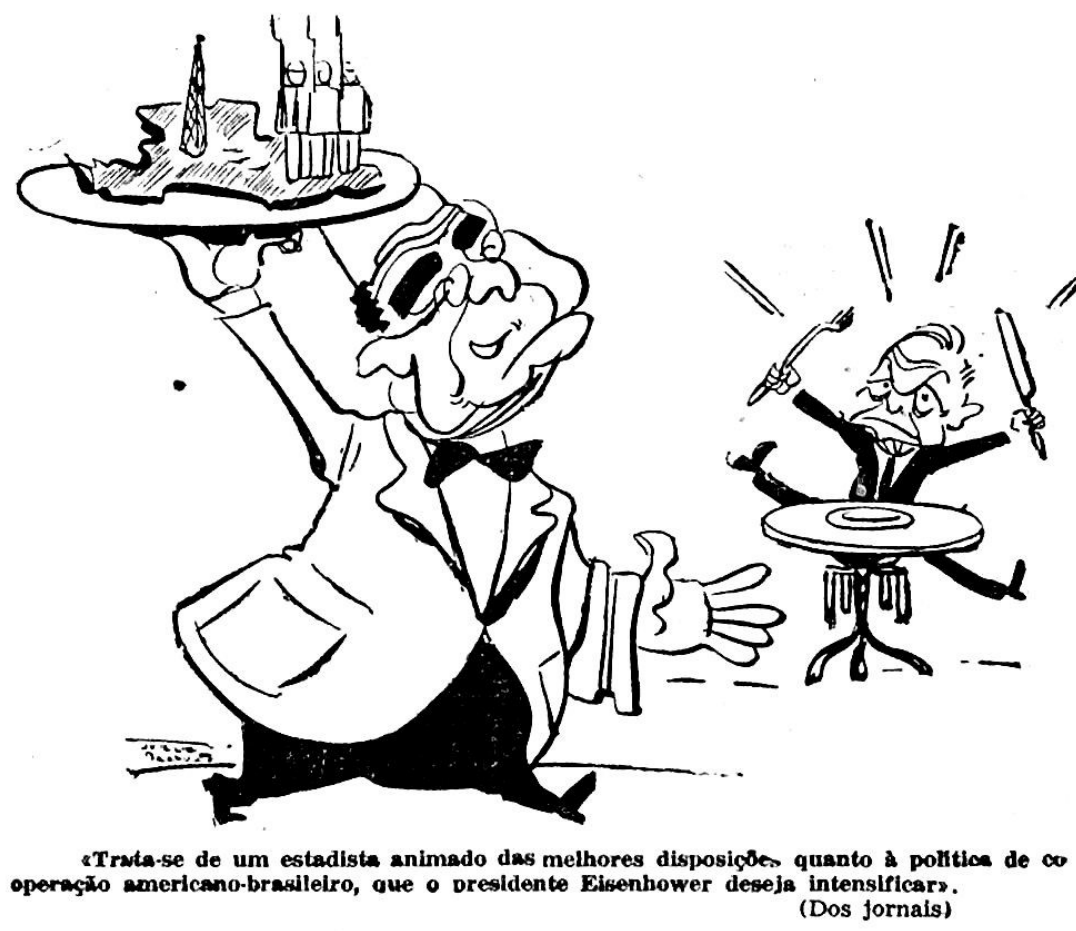

Figura 16: Voz Operária de 23 de janeiro de 1954, p.3 Fonte: Cedem/Unesp. http://www.cedem.unesp.br/

O partido ressalta as riquezas naturais e minerais que podem ser exploradas pelos americanos, e também inclui as tropas brasileiras, pois estava em uma extensa campanha contra o envio de tropas à Guerra da Coreia. Nessa campanha, a figura da mulher tem um papel importante (TORRES, 2009). O argumento era que Vargas pretendia dar, além do sangue negro (o petróleo), o sangue dos brasileiros para a máquina de guerra americana.

Talvez o desenho mais claro em suas acepções e implicações seja o publicado em Voz Operária, de 3 de julho de 1954 (Figura 17), que acompanha reportagem de página dupla sobre a submissão do presidente aos trustes ianques. A negociação de Vargas com o imperialismo ianque não ocorre com um funcionário qualquer do governo norteamericano, mas com um militar maior que Vargas. Os produtos oferecidos ao já bem abastecido comandante compõem um conjunto expressivo da economia nacional. $O$ militar tem vários "produtos" que ajudavam na máquina de guerra americana: tanto o dinheiro como o acordo militar, até o apoio internacional com o voto na Organização das Nações Unidas (ONU). 


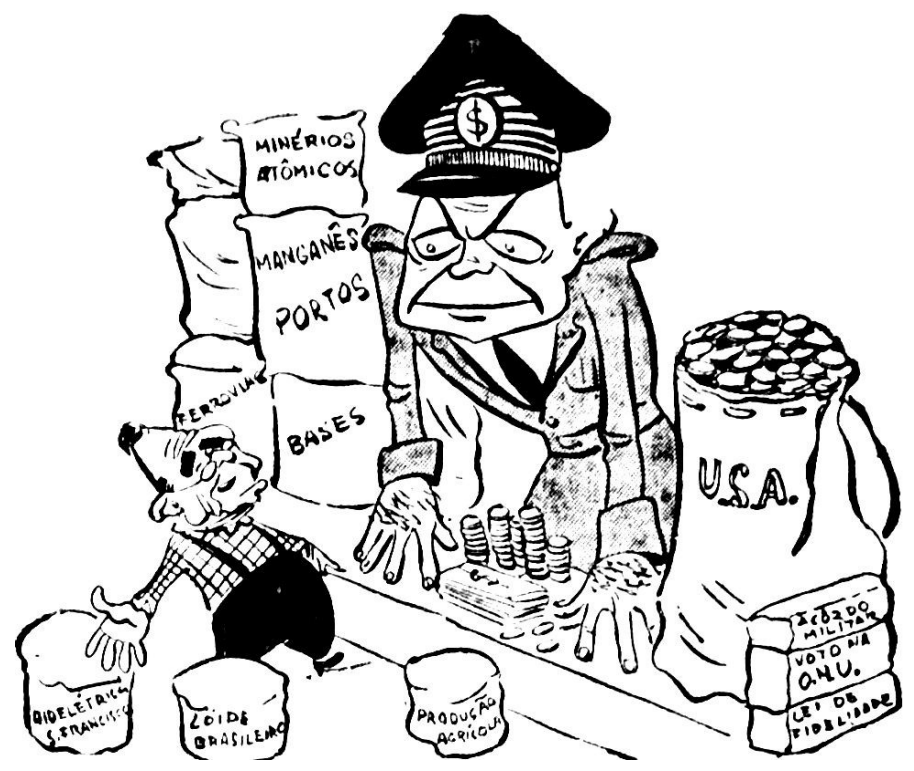

Figura 17: Voz Operária de 3 de julho de 1954, p.7

Fonte: Cedem/Unesp. http://www.cedem.unesp.br/

A exploração aos trabalhadores é destacada pela iconografia comunista, no entanto, a ênfase recai sobre a possibilidade da exploração do Brasil servir diretamente aos interesses de guerra da máquina militar norte-americana, envolvida na Guerra da Coreia (1950-1953) e em uma corrida militar contra a União das Repúblicas Socialistas Soviéticas (URSS). Dessa maneira, a exploração dos trabalhadores e a atuação do governo Vargas, no quadro maniqueísta de então, aparecem como expressão de um alinhamento a um possível ataque ao "campo da paz" e ao seu líder, a URSS. Vargas aparece de diversas maneiras para completar esse aspecto bélico. $O$ desenho publicado em Voz Operária, de 26 de abril de 1952 (Figura 18), acompanha matéria que denuncia acordo militar entre Vargas e Truman. O desenho mostra o rosto de Vargas sendo alterado até se transformar em um avião despejando a bomba atômica, arma utilizada em Hiroshima e Nagasaki por ordem de Truman.
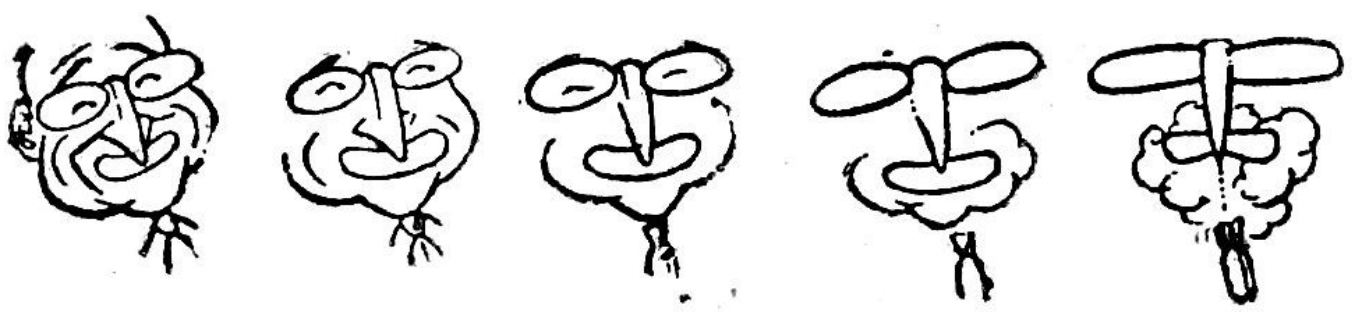

Figura 18: Voz Operária de 26 de abril de 1952, p.5. Legenda: Do sorriso à bomba atômica ou a evolução da "ajuda" americana

Fonte: Cedem/Unesp. http://www.cedem.unesp.br/ 


\section{Suicídio}

Vargas era visto como fazendeiro latifundiário autoritário, um entreguista, seguidor da ideologia moribunda do trabalhismo, mero servo de interesses, majoritariamente de guerra, dos americanos e preparador de um golpe para se perpetuar no poder. Embora várias declarações de Prestes publicadas na imprensa comunista corroborem a visão do $\mathrm{PCB}$, há dúvidas quanto à opinião prestista naquele momento.

Segundo Anita Leocádia Prestes (2016, p. 296):

Prestes esclareceu que discordara de tal orientação ... [e defendia] ser necessário mudar a tática do partido, aproximar-se de Vargas e apoiar a organização de um contragolpe. Mas o secretariado ficou quinze dias discutindo o alerta [...] e nada foi feito nesse sentido.

Após o suicídio, em uma reunião extraordinária da liderança do partido, o dirigente Diógenes Arruda, segundo Prestes (2016, p. 296), "defendeu a tese de que estariam criadas as condições para uma insurreição popular dirigida pelo PCB [e Prestes teria criticado] energicamente a proposta".

Reis (2014, p. 261) ressalta que Prestes, em declarações posteriores, afirmou que já advogava uma mudança na política de alianças do PCB desde 1949 e teria sido o autor da resolução sindical de 1952, que flexibilizou a política de alianças sindicais do partido. Reis (2014, p. 261), no entanto, afirma que "suas propostas, [...], se formuladas, desapareceram nos torvelinhos da clandestinidade". Reis (2014, p. 262-263) indica, ainda, que Prestes:

[...] insistira, mais de uma vez, a posteriori, ter sido sensível ao processo de radicalização antivarguista e antipopular, liderado pelas direitas, e em consequência disso teria formulado in extremis a proposta de aproximação com o presidente [mas] a comissão executiva [...] não teria discutido nem divulgado suas novas posições.

O texto com as propostas de Prestes:

[...] não foi encontrado nem nos arquivos, nem na memória dos velhos militantes consultados, embora sua existência tenha sido confirmada por Maria Ribeiro, segunda mulher de Prestes, que informou igualmente que o dirigente reconheceria, em conversas privadas, a responsabilidade do PCB na morte de Vargas (REIS, 2014, p. 262-263). 
A dimensão interna da suposta divergência de Prestes com a política do PCB fica envolta em dúvidas, mas a face visível do partido, expressa na imprensa, sofre uma mudança dramática com o suicídio de Getúlio Vargas. Com a grande comoção popular, o partido muda radicalmente e o humor gráfico sai de cena, mas os desenhos continuam sendo publicados. A nova postura enfatiza uma aliança com os trabalhistas, até então rivais dos comunistas. O partido publica um desenho mostrando a revolta em Franca-SP, com populares arrancando uma bandeira da União Democrática Nacional (UDN) e um incêndio ao fundo. O desenho, publicado em Voz Operária, de 11 de setembro de 1954 (Figura 19), canaliza a fúria popular exclusivamente sobre a UDN, embora os comunistas também tenham sofrido com a vingança da população. Jorge Ferreira (2005, p. 192) faz um mapeamento dos motins populares após o suicídio de Vargas, tentando identificar padrões e, na imprensa, o Última Hora foi o jornal poupado pela multidão. A Tribuna, jornal do PCB em Porto Alegre, também foi empastelado.

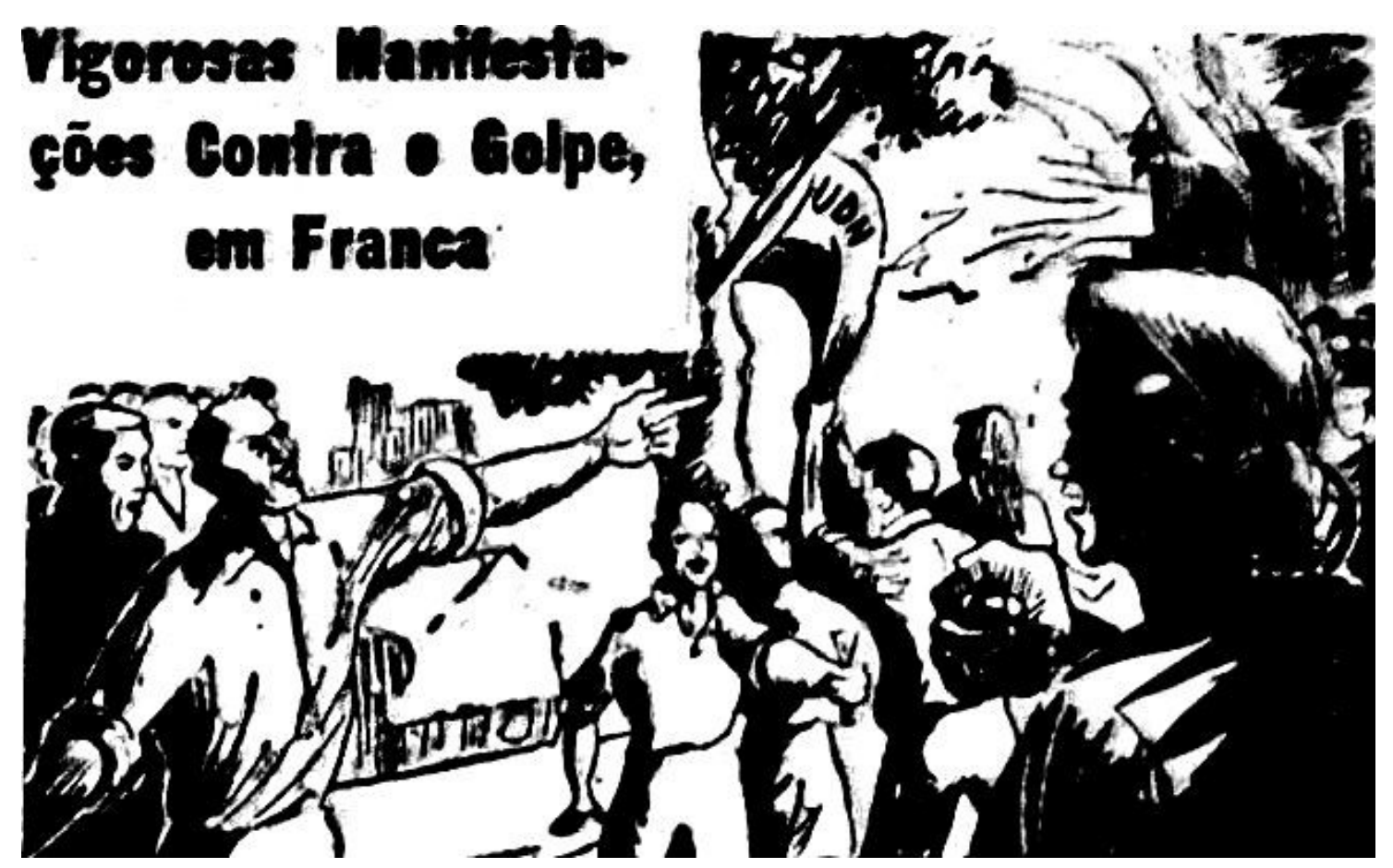

Figura 19: Voz Operária de 11 de setembro de 1954, p.7.

Fonte: Cedem/Unesp. http://www.cedem.unesp.br/ 
Getúlio, o grande rival de Luiz Carlos Prestes, criticado e ridicularizado na imprensa comunista, passa, depois de morto, a ser incorporado aos clamores populares chancelados pelo PCB. Notícias de Hoje, de 26 de setembro de 1954, publica artigo de página inteira mostrando um rosto de Prestes altivo e o título "Comunistas e trabalhistas ombro a ombro na luta contra o inimigo comum". Uma leitura possível dessa imagem é a de que Prestes também sofreu pelo povo brasileiro (embora convenientemente omita quem contribuiu para parte das suas agruras) e, portanto, os trabalhistas deviam chorar a morte de seu líder atuando a partir de agora com os comunistas. Rodrigo Patto Sá Motta (2004, p. 105) descreve o desenho em bico de pena como "um Prestes em posição heroica e máscula, olhando com firmeza para frente, com os cabelos levemente despenteados, para sugerir um homem lutador e de ação". Imprensa Popular, também de 26 de setembro de 1954, mostra um aperto de mãos ocupando a parte superior inteira do jornal, imagem tradicional de quem sela um compromisso, e usa exatamente a mesma manchete de Notícias de Hoje.

A transformação mais importante e carregada de simbologia é a incorporação do nome de Vargas como bandeira de luta dos comunistas. Após tantas críticas, o PCB acaba fazendo com o "pai dos pobres" exatamente o que ele previu na carta-testamento: fazer de seu nome uma bandeira de luta. Acompanhando a manchete "Não dar tréguas ao governo entreguista dos Café, Brigadeiro \& Cia”, o desenho publicado em Voz Operária, de 4 de setembro de 1954 (Figura 20), mostra uma multidão de brasileiros carregando faixas com os dizeres "lutemos contra o golpe", "abaixo os entreguistas" e "assassinos de Vargas". Pelo desenho, os lemas aparecem como fruto dos desejos honestos do povo brasileiro, que, aqui, são somados às reivindicações do $\mathrm{PCB}$. O suicídio de Vargas se transforma em assassinato, mas o partido rapidamente aponta o dedo aos assassinos, e tira o foco de sua campanha contra Vargas. Prestes podia admitir em privado a responsabilidade do partido no suicídio de Vargas, mas nos desenhos comunistas os assassinos eram outros e o trabalhismo, então, era um aliado. 


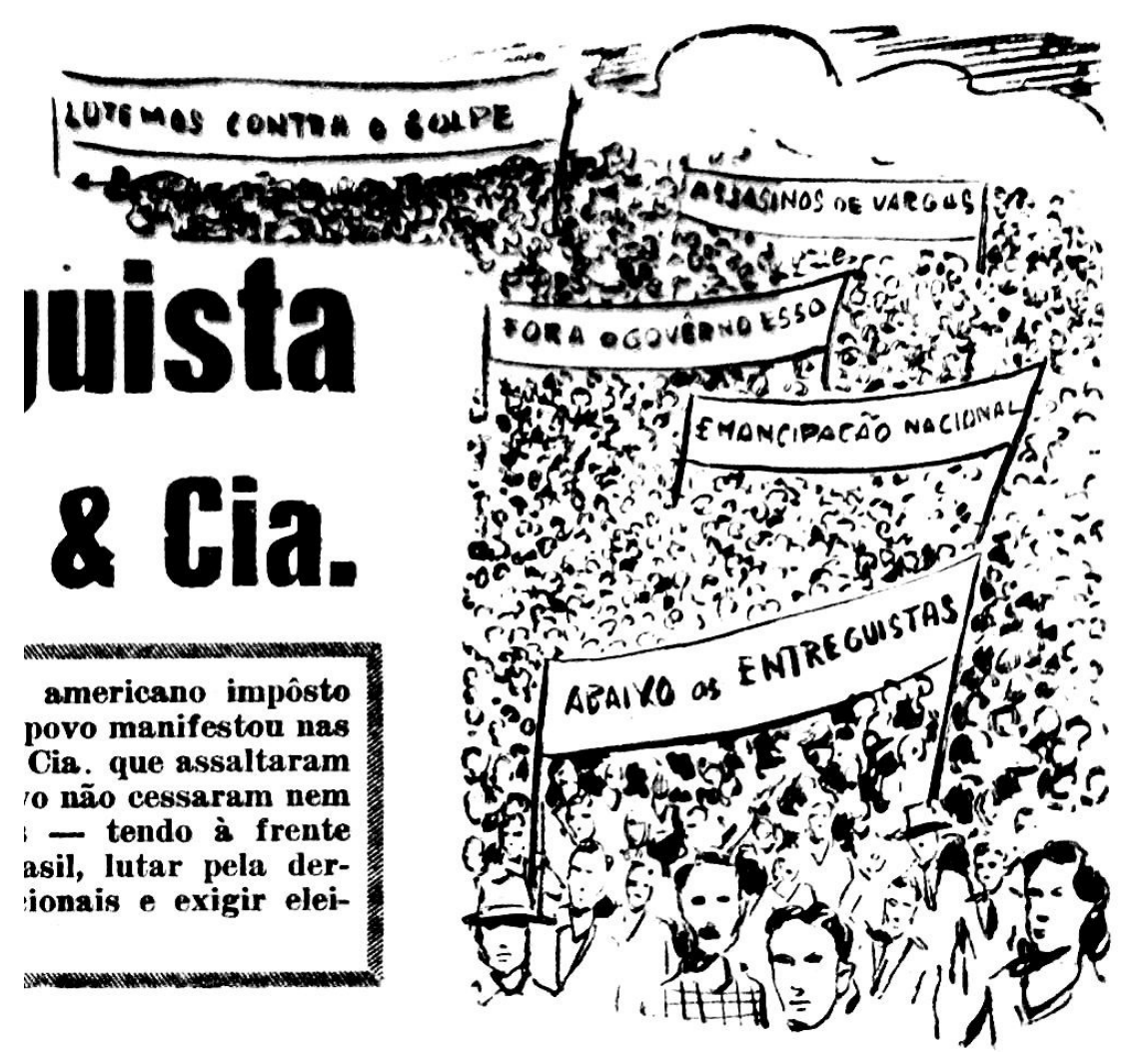

Figura 20: Voz Operária de 4 de setembro de 1954, p.10 Fonte: Cedem/Unesp. http://www.cedem.unesp.br/

\section{Referências}

ABEDELMALACK, Genny. Momentos da história do Brasil através da caricatura 1900-1937. 1991. Dissertação (Mestrado em Comunicação) - Universidade de São Paulo - Escola de Comunicação e Artes, São Paulo, 1991.

AMADO, Jorge. O Cavaleiro da esperança. Rio de Janeiro: Editora Record, 1979.

AMARAL, Aracy. Arte para quê? a preocupação social na arte brasileira: 1930-1970. São Paulo, Nobel, 1984.

BONNEL, Victoria. Iconography of power: soviet political posters under Lênin and Stálin. Berkeley: University of Califórnia, 1997

CANETTI, Elias. Massa e poder. São Paulo: Companhia Das Letras, 1995. 
CAPELATO, Maria Helena. Multidões em cena: propaganda política no varguismo e no peronismo. São Paulo: Papirus, 1998.

CAVALCANTI, Laílson de Holanda. Historia del Humor Gráfico em el Brasil. Lleida: Milenio, 2005

CENTRO DE DOCUMENTAÇÃO E MEMÓRIA DA UNESP. Local: CEDEM/UNESP. Data Disponível em: <http://www.cedem.unesp.br/>. Acesso em 12 de setembro de 2016.

CHEVALIER, Jean; GHEERBRANT, Alain. Dicionário de símbolos: mitos, sonhos, costumes, gestos, formas, figuras, cores, números. Rio de Janeiro: José Olympio, 2003.

CUSHING, Lincoln. Revolución! cuban poster art. San Francisco: Chronicle Books, 2003.

DAVIES, Christie. Cartuns, caricaturas e piadas: roteiros e estereótipos. In. LUSTOSA, Isabel. Imprensa, humor e caricatura: a questão dos estereótipos culturais. Belo Horizonte: Editora da UFMG, 2011.

EVANS, Harriet; STEPHANIE, Donald. Picturing power in the people's republic of China: posters of the Cultural Revolution. Lanham, Md: Rowman \& Littlefield, 1999.

FERREIRA, Jorge. Prisioneiros do mito: cultura e imaginário político dos comunistas no Brasil. Rio de Janeiro: UFF, 2003.

FERREIRA, Jorge. O imaginário trabalhista: getulismo, PTB e cultura política popular 19451964. Rio de Janeiro, Civilização Brasileira, 2005.

FLORES, Elio Chaves. Danações da República: imagens cômicas do getulismo. Saeculum (UFPB), João Pessoa, v. 5, p. 233-250, 1999.

FLORES, Elio Chaves. Representações cômicas da República no contexto do getulismo. Revista Brasileira de História, São Paulo, v. 21, p. 133-157, 2001.

FRANCASTEL, Pierre. A realidade figurativa. São Paulo: Perspectiva, 1982.

GARCÍA, Hamilcar. Dicionário contemporâneo da língua portuguesa Caldas Aulete. Rio de Janeiro: Delta, 1980.

GAWRYSZEWSKY, Alberto. Os traços na imprensa comunista carioca. 2004. Versão modificada do trabalho de Pós-doutorado em História Social do Departamento de História da Universidade Federal Fluminense. Universidade Federal Fluminense, 2004. 
GAWRYSZEWSKY, Alberto. Conceito de caricatura: não tem graça nenhuma. Revista Domínios da Imagem, n. 02, maio de 2008.

GAWRYSZEWSKY, Alberto. Arte visual comunista: imprensa comunista brasileira 1945 1958. 1. ed. Londrina: LEDI/Universidade Estadual de Londrina, 2010.

GONÇALVES, Cassandra de Castro Assis. Clube de Gravura de Porto Alegre: arte e política na modernidade. 2005. Dissertação (Mestrado em Interunidades de Estética e História da Arte) - Universidade de São Paulo, São Paulo, 2005.

LAGO, Pedro Corrêa. Caricaturistas Brasileiros: 1836 - 1999. Rio de Janeiro: Sextante, 1999.

LANDSBERGER, Stefan. Chinese Propaganda Posters: from revolution to modernization. Armonk, N.Y.: M.E. Sharpe, 1995.

LENHARO, Alcir. Sacralização da política. Campinas: Papirus, 1986.

LIMA, Herman. História da caricatura no Brasil. Rio de Janeiro: Editora José Olímpio, 1963.

MANGUEL, Alberto. Lendo imagens: uma história de amor e ódio. São Paulo: Companhia das Letras, 2001.

MARTINS, Angela. Pelas páginas libertárias: anarquismo, imagens e representações. 2006. Tese (Doutorado em História) - Pontifícia Universidade Católica de São Paulo, Local, 2006.

MICELI, Sergio. Imagens negociadas: retratos da elite brasileira, 1920-40. São Paulo: Companhia das Letras, 1996.

MORAES, Denis. O Imaginário vigiado: a imprensa comunista e o realismo socialista no Brasil (1947-53). Rio de Janeiro: Jose Olympio, 1994.

MOTTA, Rodrigo Patto Sá. Em guarda contra o perigo vermelho: o anticomunismo no Brasil, 1917-1964. São Paulo: Editora Perspectiva, 2002

MOTTA, Rodrigo Patto Sá. Batalhas em torno do Mito: Luiz Carlos Prestes. Estudos Históricos, Rio de Janeiro, n.34, p.91-115, jul.-dez. 2004.

MOTTA, Rodrigo Patto Sá. Jango e o Golpe de 1964 na caricatura. Rio de Janeiro: Jorge Zahar, 2006. 
MOTTA, Rodrigo Patto Sá. A figura caricatural do gorila no discurso de esquerda, ArtCultura, Uberlândia: nº.15, p. 195-212, jul.-dez. 2007.

MOTTA, Rodrigo Patto Sá. A Cultura política comunista: alguns apontamentos. In. NAPOLITANO, Marcos; CZAJKA, Rodrigo; MOTTA, Rodrigo (orgs.). Comunistas brasileiros: cultura política e produção cultural. Belo Horizonte: Editora UFMG, 2013.

NOGUEIRA, Andrea de Araújo. Humor e populismo: o desafio diário nas charges de Nelo Lorenzon (1948-1960). 2005. Tese (Doutorado em Comunicação) - Escola de Comunicação e Artes da USP, São Paulo, 2005.

POMAR, Pedro. Comunicação, cultura de esquerda e contra-hegemonia: o jornal hoje (1945-1952). 2006. Tese (Doutorado em História) - Faculdade de Filosofia Letras e Ciências Humanas, Universidade de São Paulo, São Paulo, 2006.

PRESTES, Anita Leocádia. Luiz Carlos Prestes: um comunista brasileiro. São Paulo: Editora, 2016.

REIS, Daniel Aarão. Luís Carlos Prestes: um revolucionário entre dois mundos. São Paulo: Cia das Letras, 2014.

RUBIM, Antônio. Partido Comunista, cultura e política cultural. 1986. Tese de Doutorado em Sociologia. 1986

SILVA, Marcos. A construção do saber histórico: historiadores e imagens. Revista História, São Paulo, n. 125-126, ago-dez. 1991 a jan-jul. 1992.

SOARES, Paula. As Representações do camponês e do latifundiário brasileiros: trabalhadores rurais e coronéis na cultura política comunista (1922-1964). 2011. Dissertação (Mestrado em História) - Universidade Federal de Minas Gerais, Local, 2011.

TAVARES, Rodrigo Rodriguez. Um panorama do humor gráfico no Brasil. Domínios da imagem (UEL), v. 1, p. 141-145, 2008.

TAVARES, Rodrigo Rodriguez. Desenhando a Revolução: a luta de imagens na imprensa comunista (1945-1964). 2010. Tese (Doutorado em História Social) - Faculdade de Filosofia, Letras e Ciências Humanas, São Paulo, 2010.

TORRES, Juliana. A Representação visual da mulher na imprensa comunista. 2009. Dissertação (Mestrado em História) - Programa de Pós-Graduação em história Social. UEL, Londrina, 2009.

WAINER, Samuel. Minha razão de viver: memórias de um repórter. 8. ed. Rio de Janeiro: Record, 1988. 
WHITE, Stephen. The bolshevik poster. New Haven: Yale University Press, 1988.

Recebido em 11/07/2016 Aprovado em 26/08/2016

Universidade do Estado de Santa Catarina - UDESC

Programa de Pós-Graduação em História - PPGH

Revista Tempo e Argumento Volume 08 - Número 18 - Ano 2016 tempoeargumento@gmail.com 